SOUTH EAST EUROPE

Jointly for our common future
SNAPORSE

Planning Aggregates Supply

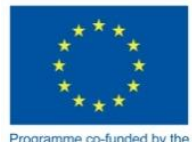

Prome cotunded by the EUROPEAN UNION

Kako izraditi održiv plan za agregate

Prosinac 2014

RegioneEmilia-Romagna 



\section{Kako izraditi održiv plan za agregate}

\section{Temeljeno na:}

Radu i iskustvu projektnih partnera u okviru Radnog paketa 6 SNAP-SEE Projekta „Održivo planiranje kamenih agregata u jugoistočnoj Europi“ (SEE/D/0167/2.4/X)

Web stranica: http://www.snapsee.eu

Ostvareno u Aktivnosti 6.2: Zajednička transnacionalna shema za planiranje agregata

\section{Informacije o publikaciji}

$\begin{array}{ll}\text { Izdanje i priprema: } & \text { Foteini Stathogianni, Urška Dolinar } \\ \text { Dizajn naslovnice: } & \text { Stelios Mavrigiannakis } \\ \text { Tisak: } & \text { Hrvatski geološki institut } \\ \text { Godina izdanja } & 2014\end{array}$

Prijevod i prilagodba na hrvatski jezik:

Kovačevič Galović Erli, dipl. ing., Hrvatski geološki institut (HGI), Hrvatska

Lektorirao:

Peh, Zoran, dr. sc., Hrvatski geološki institut (HGl), Hrvatska

\section{Odricanje od odgovornosti}

Ova SNAP-SEE publikacija odražava samo mišljenje autora te Upravno tijelo Programa za transnacionalnu suradnju u jugoistočnoj Europi ne preuzima odgovornost za bilo kakve moguće radnje temeljene na informacijama sadržanima u njoj. CSNAP-SEE projekt 2014 
Severi Paolo Geological, seismic and soil survey

Bonzi Luciana Geological, seismic and soil survey

Cintoli Stefano Waste and sites remediation, Water and waste public services and ICT

Marasmi Christian Soil and Coast Protection and Reclamation Service

RegioneEmilia-Romagna Ratta Manuela Waste and sites remediation, Water and waste public services and ICT

Rizzati Anna Rita Soil and Coast Protection and Reclamation Service

Romagnoli Massimo Soil and Coast Protection and Reclamation Service

Segadelli Stefano Geological, seismic and soil survey

Furin Stefano Consultant at Geological, seismic and soil survey

\section{Recenzenti}

\begin{tabular}{ll}
\hline Ime & Institucija \\
\hline Shields, Deborah J., Dr. & Colorado State University, United States of America \\
Agioutantis, Zacharias & Technical University of Crete, Greece \\
Tiess, Guenter & Montanuniversität Leoben (University of Leoben), Austria \\
& \\
Priznanje & \\
Partneri SNAP-SEE projekta zahvaljuju Europskoj komisiji na financiranju ovog projekta koji je doveo do \\
plodne suradnje među partnerima koji dijele slične problem i zajedničku viziju te omogućio razvoj ovog \\
priručnika.
\end{tabular}

\section{Identifikator digitalnog objekta (DOI):}

doi: 10.5474/snapsee-WP6-HR

\section{Citiranje}

Ovaj priručnik se u bibliografiji citira na sljedeći način: Severi et al. (2014): How to Build a Sustainable Aggregates Plan (SNAP-SEE project), WP6 Report

doi: 10.5474/snapsee-WP6-HR 


\section{Kako izraditi održiv plan za agregate}

1 Stanje planiranja u JIEE 6

1.1 Planiranje primarnih i sekundarnih agregata.................................................. 8

1.2 Centralizirani ili decentralizirani pristup? .............................................................. 14

1.3 O složenosti izrade plana za mineralne sirovine .................................................... 18

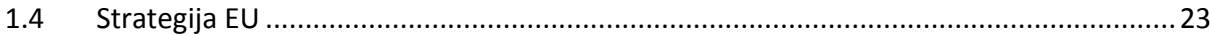

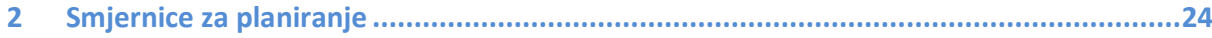

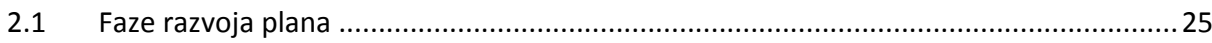

2.1.1 Prva faza: Preliminarni dokument........................................................... 25

2.1.2 Druga faza: Razmjena podataka................................................................. 26

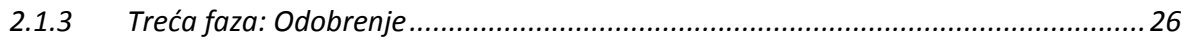

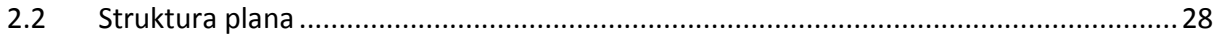

2.2.1 Utvrđivanje potrebe za državnim planom za kamene agregate .......................... 29

2.2.2 Uklapanje plana za kamene agregate u opći plan korištenja prostora.................. 30

2.2.3 Utvrđivanje vlasništva nad primarnim agregatima ............................................. 30

2.2.4 Pozivanje na načela dogovorena na nivou Europe............................................ 31

2.2.5 Predviđanje buduće potražnje za kamenim agregatima.................................... 31

2.2.6 Identifikacija zona prioriteta i zona zaštite ..................................................... 32

2.2.7 Identifikacija alternativnih izvora............................................................ 34

2.2.8 Definiranje kriterija i smjernica za lokalna područja eksploatacije ......................... 34

2.2.9 Osiguravanje konkurentnosti u industriji agregata......................................... 35

2.2.10 Usvajanje najboljih dostupnih tehnologija tijekom cjelokupnog procesa............ 36

2.2.11 Definiranje kriterija konačne iskoristivosti nakon zatvaranja .............................37

2.2.12 Uspostavljanje koordinacije između tijela nadležnih za izdavanje dozvola .......... 38

2.2.13 Postupci za izdavanje dozvola trebaju biti djelotvorni i učinkoviti....................... 39

2.2.14 Provođenje potrebe za ravnotežom u okolišu ............................................. 40 


\section{Predgovor}

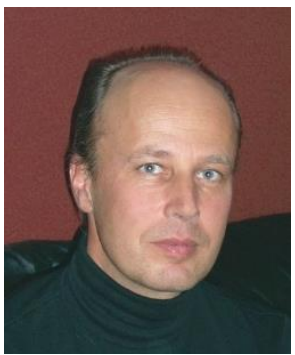

Države u jugoistočnoj Europi (JIE) su bogate građevinskim agregatima, tj. tehničko-građevnim kamenom, šljunkom, pijeskom i ostalim zrnatim inertnim materijalima koji se koriste u građevinskoj industriji; međutim, ovi resursi nisu ravnomjerno raspoređeni u cijeloj regiji, što rezultira izobiljem u nekim područjima i nestašicom u drugima. Nadalje, pristup tim resursima postaje sve teži zbog izgradnje drugih infrastruktura te ograničenja vezanih uz zaštitu okoliša. S obzirom da su agregati teški i glomazni, a prijevoz je skup, dostupnost resursa u blizini tržišta od presudne je važnosti. Regija JIE će do 2020. vjerojatno zahtijevati $50 \%$ veću proizvodnju agregata kako bi zadovoljila svoje rastuće infrastrukturne potrebe.

Dakle, postoji potreba za prijelaz na održivo gospodarenje resursima agregata (SARM) i osiguranje održive mješovite opskrbe (SSM) agregata u regiji kako bi se poboljšala učinkovitost resursa i podržao održivi razvoj. SARMa je učinkovit, s niskim društveno-okolišnim utjecajem eksploatacije i gospodarenja otpadom, zajedno sa širim sudjelovanjem dionika. SSM se sastoji od opskrbe agregata iz više izvora, uključujući i reciklirani građevinski otpad i industrijske nusproizvode (šljake), kao i domaću proizvodnju i uvozu primarnih materijala, koji zajedno povećavaju mrežu koristi od opskrbe agregata kroz generacije.

Provedba SARM i SSM zahtijeva podržava okvir politike i planiranja. Zbog regionalnih razlika i povijesnog razvoja, pristupi politikama o agregatima, planiranju i gospodarenju razlikuju se na različitim političkim razinama unutar i diljem jugoistočne Europe, a u nekoliko slučajeva su potpuno sveobuhvatne. Izazovi uključuju politiku i planove koji zahvaćaju gospodarenje agregatima i odredbu da su distribuirani između mnogih različitih pravnih dokumenta, što otežava koordinaciju i sveobuhvatno razumijevanje. Tu je i nedostatak koordinacije u planiranju opskrbe iz primarnih $\mathrm{i}$ sekundarnih agregata. Jl Europa nema dovoljno podataka da bi podržala planiranje agregata, ne posjeduje dovoljnu sposobnost i stručnost za rješavanje planiranja primarnih $\mathrm{i} / \mathrm{ili}$ sekundarnih agregata uz nedovoljno sudjelovanje dionika u izradi planova gospodarenja agregatima. Projekt SNAP-SEE je naglasio te slabosti, kako bi potaknuo snažan rast odgovorne $\mathrm{i}$ održive industrije agregata u regiji jugoistočne Europe.

Specifična svrha održivog planiranja agregata u jugoistočnoj Europi u okviru SNAPSEE projekta bio je stvoriti i distribuirati alate za planiranje agregata da pomognu suradnju vlasti i dionika u Jl Europi kako bi unaprijedili svoje procese planiranja i gospodarenja agregatima. SNAP-SEE je stvoren na rezultatima održivog gospodarenja 
kamenim agregatima (SARMa) projekta, prethodni projekt financiran kroz transnacionalne programe jugoistočne Europe (http://www.sarma.eu). SNAP-SEE je također financiran kroz transnacionalne programe jugoistočne Europe (SNAP-SEE, vidjeti/D/0167/2.4/x) i imao je 27 partnera iz 12 zemalja jugoistočne Europe i Tursku. Vodeći partner na projektu je bilo Sveučilište u Leobenu, Austrija. SNAP-SEE je bio dvogodišnji projekt koji je završio u studenom 2014.

SNAP-SEE alati za planiranje agregata sadrže 4 proizvoda koja su međusobno povezana i međusobno se podržavaju.

1. Vizija najboljih praksi u planiranju agregata u jugoistočnoj Europi

Ovaj dokument predstavlja Viziju za prijelaz na integrirano, sveobuhvatno održivo planiranje u jugoistočnoj Europi. To uključuje rasprave o problemima koje treba rješavati, privremene mjere koje se mogu poduzeti prema održivom planiranju i pregled komponenti koje bi održivi plan trebao sadržavati.

2. Kako izgraditi održivi plan za agregate

Dokument 'Kako' predstavlja putokaz za planiranje, uključujući i rasprave o procesu planiranja i njegovih različitih koraka. Dani su primjeri dobro napisanog modula planiranja koji utjelovljuju načela, pristupe i akcije potrebne za postizanje ciljeva Vizije postavljenih u izvješću o najboljim praksama.

3. Savjetovanje dionika prilikom primjene najboljih praksi u održivom planiranju agregata

U dokumentu "Konzultacije" omogućuje se korak-po-korak vodič za planiranje i provedbu savjetovanja dionika kako bi se osiguralo da industrija, vlada, nevladine organizacije i građansko društvo mogu pružiti ulazne podatke i sudjelovati u procesu planiranja. Također su dostupni materijali o izgradnji kapaciteta.

4. Podaci i metodologije analize u planiranju agregata: potpora najboljim praksama u održivom planiranju agregata

Dokument 'Podaci i analiza' razmatra različite vrste podataka koji daju osnovnu informaciju i spoznaje za proces planiranja. Obuhvaćene su definicije podataka, značaj, dostupnost, struktura i potrebe. Predstavljene su metode provjere i analiziranja podataka, uključujući pristupe prognozama zahtjeva.

Koordinator projekta

Guenter Tiess

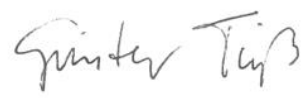

Montanuniversitaet Leoben

(Sveučilište Leoben) 


\section{Stanje planiranja u JI Europi}

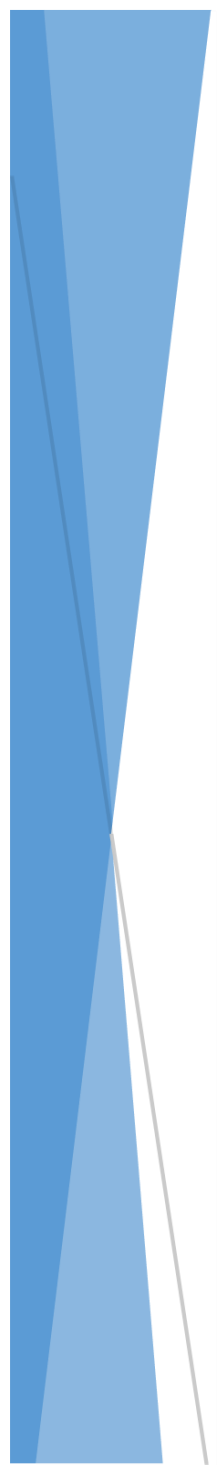

Kad se želi postići održivi regionalni razvoj, osiguravanje održive opskrbe kamenim agregatima je važan izazov zbog njihove ograničene dostupnosti. Zbog regionalnih razlika $i$ povijesnog razvoja u zemljama jugoistočne Europe javljaju se različiti pristupi politici, planiranju i gospodarenju agregatima, što smanjuje učinkovitost resursa i gospodarski razvitak u regiji. Svrha projekta SNAP-SEE je omogućiti poboljšanja u planiranju kamenih agregata u jugoistočnoj Europi kako bi se postigao taj cilj. 
Jedna od osnovnih karakteristika postojećih planova mineralnih sirovina diljem EU je rascjepkanost pojedinih politika između različitih nadležnih tijela, različitih sektorskih planova i različitih razina napredovanja. Pomoću grafičkog pristupa opisanog u ovom poglavlju naglašene su zainteresirane strane uključene u postupak planiranja, kao i odnosi između različitih nivoa zakonodavstva i dokumenata koji od njih potiču, a kojima se daju ovlaštenja. Ovaj pristup nadopunjuju analize navedene u Horváth i dr. (2014) te Agioutantis i dr. (2014), a koje su uključene u ovaj Alatni okvir.

$U$ većini država članica poseban Zakon o rudarstvu regulira i eksploataciju mineralnih sirovina koje su u vlasništvu države. Mnoge države jugoistočne Europe (JIE) također imaju i politiku mineralnih sirovina. Sektorske politike predstavljaju ciljeve vlade, jer potpomažu gospodarski, društveni i ekološki razvoj jedne zemlje. Politike definiraju državnu strategiju, a zatim slijedi razvoj planova. Planiranje je prema tome stvaranje službenih procedura koje treba slijediti da bi se postigli ciljevi. Provođenje planova predstavlja obavezu upravnih tijela.

lako zakoni o rudarstvu postoje, usvajanje posebnih politika i planova ne predstavlja tako široko rasprostranjenu praksu; međutim kreiranje ovakvih planova je proces koji je u tijeku i predstavlja odličnu priliku za usvajanje održivih pristupa u regiji.

Kao primjer procesa u tijeku možemo uzeti situaciju u Crnoj Gori (slika 1): Prostorni plan Crne Gore za period do 2020. je dokument koji postavlja dugoročne temelje za organizaciju i prostorno uređenje u zemlji do 2020. godine. Ovaj državni plan je opće prirode, ali kada je riječ o mineralnim sirovinama jedna od točaka plana zahtjeva da se napravi procjena postojećih mineralnih sirovina u zemlji, procjena rezervi, lokacije/mjesta ležišta mineralnih sirovina, kao i lokacije/mjesta na kojima je eksploatacija do sada obavljana.

U spomenutoj zemlji, planiranje koje se odnosi na proizvodnju agregata obuhvaćeno je s dva različita zakona: Zakonom o koncesijama i Zakonom o rudarstvu. Najvažniji pravni akt u vezi planiranja agregata je Zakon o rudarstvu, kojim se definira obveza usvajanja državnog plana eksploatacije mineralnih sirovina, a koji se sastoji od općeg plana i plana eksploatacije određenih mineralnih sirovina. Također, Zakon o koncesijama definira da se koncesije, koje predstavljaju jedini način da se dobije pravo na istraživanje i eksploataciju mineralnih sirovina, dodjeljuju na temelju dugoročnog plana kojeg je usvojila Vlada. Istraživanje i eksploatacija mineralnih sirovina u Crnoj Gori uređuje se koncesijama koje država dodjeljuje tvrtkama na temelju godišnjeg plana dodjele koncesija. Vlada Crne Gore usvaja godišnji plan nakon javne rasprave koju provodi Ministarstvo gospodarstva kada je riječ o tehničko-građevinskom kamenu (drobljenom kamenu), odnosno pijesku i šljunku koji se ne eksploatiraju iz rijeke, a kada su u pitanju riječni šljunak i pijesak, javnu 
raspravu provodi Uprava za vode. Koncesijski plan, između ostalog, utvrđuje i lokacije za koje se daju koncesije.

Kada je u pitanju politika gospodarenja otpadom treba spomenuti i Nacionalnu politiku gospodarenja otpadom, Strateški master plan gospodarenja otpadom i Studiju o ocjeni potrebe za revizijom Strateškog master plana za gospodarenje otpadom u Crnoj Gori, kao i Preporuke za organizaciju poslova gospodarenja otpadom za period do 2030. Zakon o gospodarenju otpadom predstavlja zakonodavni okvir u području gospodarenja otpadom. Zakon je usvojen 2011. Također su usvojeni i neki popratni zakonodavni akti.

Prema tome, dugoročno planiranje i buduća integracija različitih izvora agregata su izvedivi, a zakonodavstvo koje definira potrebu gospodarenja agregatima postoji, ali u ovom trenutku Crna Gora još nije razvila precizan plan za kamene agregate. Planovi koji se odnose na mineralne sirovine, a prvi među njima je Državni plan eksploatacije mineralnih sirovina, vode ka učinkovitosti resursa i teoretski su kompatibilni sa SARM i SSM ciljevima.

\subsection{Planiranje primarnih i sekundarnih agregata}

Neophodnost smanjivanja upotrebe neobnovljivih prirodnih izvora resursa i, istovremeno, smanjivanja negativnih utjecaja koji se javljaju tijekom proizvodnje i gospodarenja otpadom iz građevinskog sektora doveli su do sve većeg interesa za recikliranjem, naročito kada je u pitanju Europska komisija. Stoga mogućnost oporabe dijela otpada i njegovog vraćanja u proizvodni ciklus u obliku proizvoda ili sirovina djeluje izazovno.

Kulturalni otpor prema upotrebi recikliranih agregata, uvjetovan činjenicom da potječu od otpada, jedna je od glavnih prepreka razvoju industrije recikliranja agregata. Kako bi se otklonile sve predrasude korisnika potrebno je, u skladu sa Direktivom 2008/98/EC, što je prije moguće definirati kriterije pomoću kojih se određuje trenutak u kojem otpad prestaje biti to što je i postaje koristan materijal (Bressi i dr., 2011).

Onda kada sekundarni agregati izgube status otpada, mogu se smatrati alternativnim izvorom materijala za posebne namjene. Zbog ove „promjene stanja“, trenutno se $u$ mnogim državama jugoistočne Europe politike i planovi u vezi sa primarnim i sekundarnim agregatima ne nalaze u jednom zajedničkom dokumentu; oni su rasuti kroz mnogo različitih pravnih akata, zbog čega su koordinacija i temeljno razumijevanje ovog problema vrlo teški. Također postoji i sveprisutni nedostatak koordinacije kad je riječ o planiranju opskrbe primarnim i sekundarnim agregatima.

Budući da su sekundarni agregati od ključnog značaja kao zamjena za upotrebu neobnovljivih agregata i za smanjenje negativnih utjecaja na okoliš, tijela nadležna za 
planiranje trebala bi utvrditi obujam sekundarnih resursa koji se mogu koristiti kao agregati. Korištenje recikliranih agregata je u porastu kako sve veći broj zemalja prilagođava svoje ciljeve i politike u planiranju kamenih agregata (Agioutantis i dr., 2014).

U državama jugoistočne Europe u tijeku je proces uspostavljanja popisa različitih sekundarnih agregata, ili barem registra potencijalnih izvora takvih agregata. Postoje mnogi primjeri, ali trenutno su najpotpunije podatke o potencijalnim izvorima prikupili Autonomna Pokrajina Trento (slika 2) i Hrvatska (slika 3), gdje se također vrše procjene ili prikupljaju podaci za agregate koji se iskopavaju u građevinskim radovima, dok Slovenija (slika 4), Srbija, Slovačka i Austrija prikupljaju podatke o postocima količine proizvoda od recikliranih sekundarnih agregata.

\section{Akronimi korišteni u nacionalnim shemama (Slike 1-9):}

Inter. Com.: Interdisciplinarni odbor;

S.E.A.: Strateška procjena zaštite okoliša;

E.I.A.: Procjena utjecaja na okoliš;

M.I.E.: Ministarstvo industrije i gospodarstva;

M.o.E: Ministarstvo gospodarstva;

N.C.L.: Nacionalni centar za dozvole;

Uvećane verzije shema predstavljenih na sljedećim stranicama dostupne su na web stranici SNAP-SEE projekta www.snapsee.eu. 


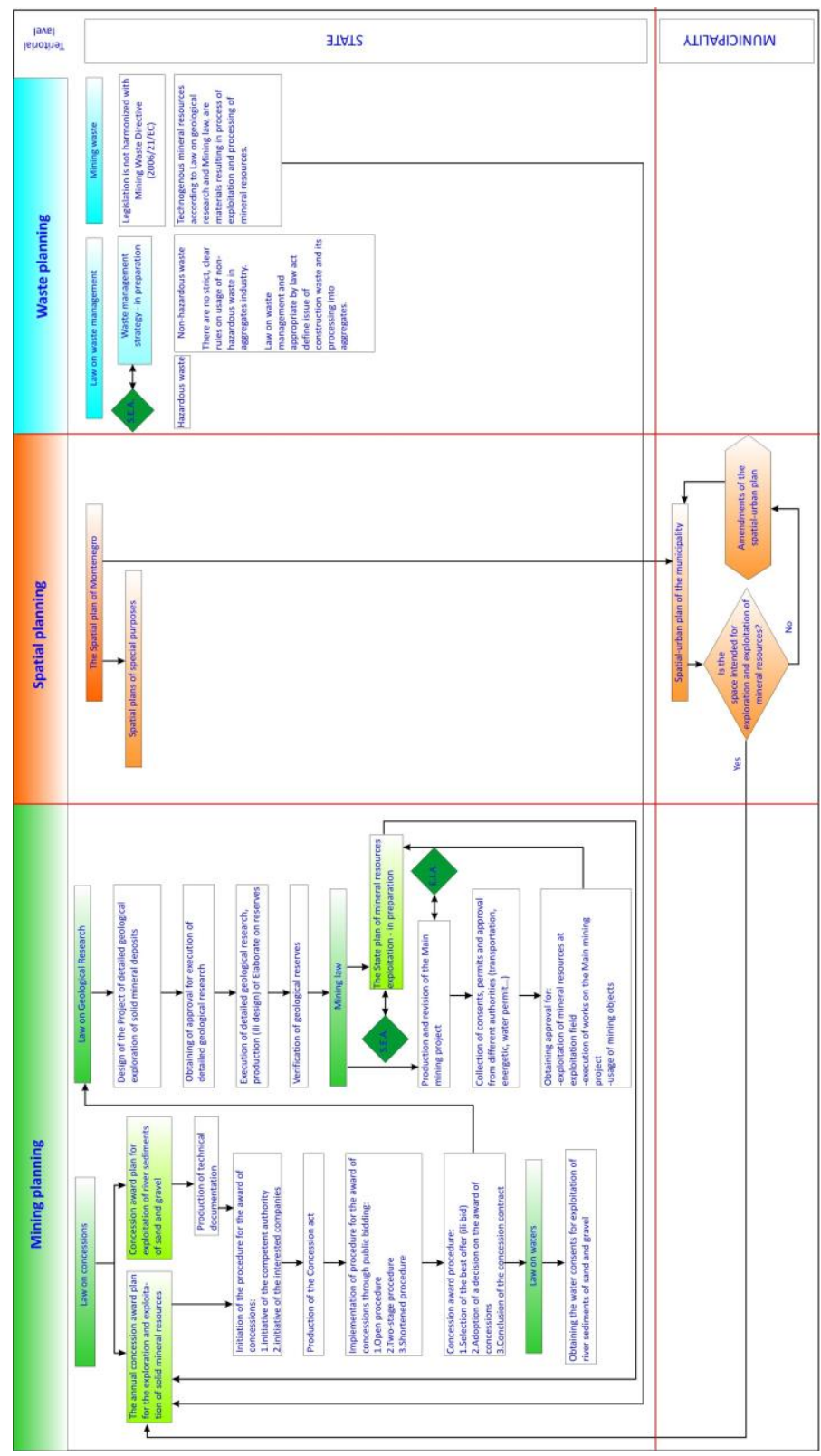

Slika 1 - Odnos između prostornog planiranja i postupaka za dobivanje prava na istraživanje i eksploataciju mineralnih sirovina u Crnoj Gori. 


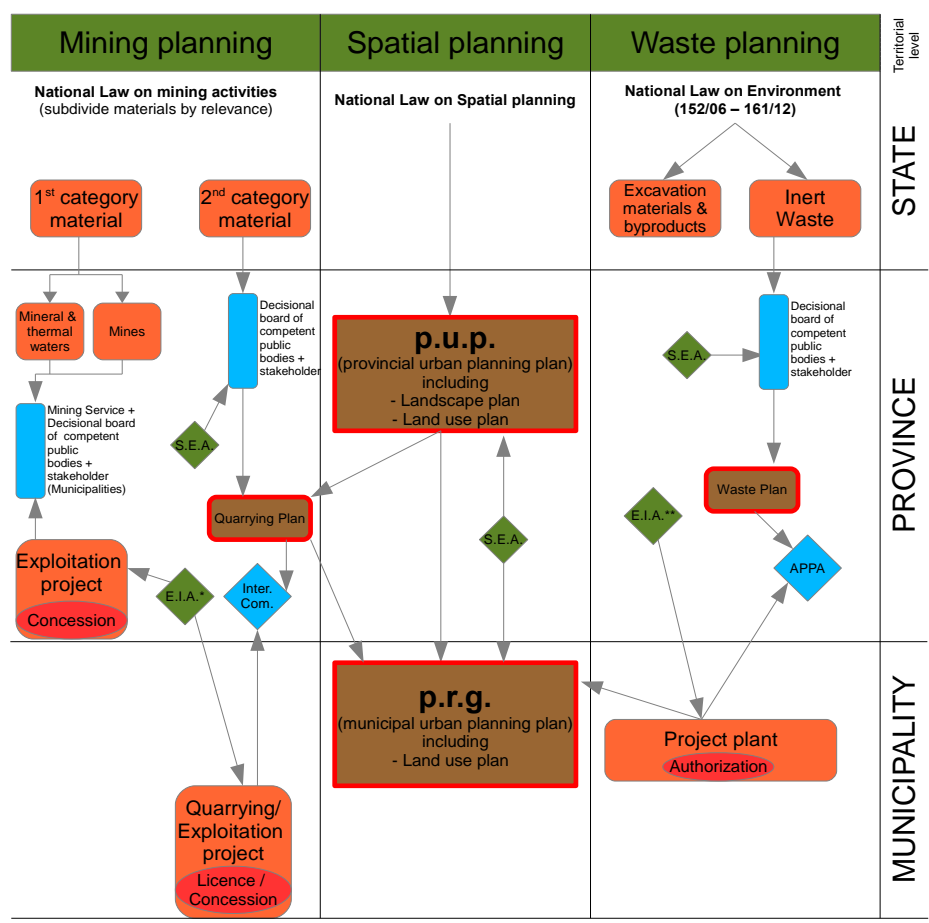

Slika 2 - Shema prostornog planiranja u Pokrajini Trento (Italija): postupci planiranja eksploatacije i prostornog planiranja mogu se usporediti s onima u pokrajini Emilia-Romagna (vidi sliku 6), dok je plan gospodarenja otpadom usvojen ranije. Interdisciplinarni odbor $u$ pokrajini Trento je uspostavljen na osnovu zakona pokrajine, a procjenjuje sve projekte eksploatacije u pokrajini. Odbor saziva Služba za rudarstvo, a sastavljen je od APPA-e, Službe za zaštitu okoliša, Službe za šumarstvo i faunu, Geološke službe, Službe za urbano planiranje i vanjskog stručnjaka (kojeg odabire industrijska udruga). Odbor procjenjuje projekte i daje pozitivno ili negativno obvezujuće mišljenje, ali općina je zadužena za izdavanje dozvole ili koncesije na osnovi tog mišljenja. *: pokrajinski zakon LP 28/1988 određuje granice iznad kojih je potrebna procjena utjecaja na okoliš. Za eksploataciju više od $200.000 \mathrm{~m}^{3}$ materijala potreban je postupak projekcije, dok je za eksploataciju više od $500.000 \mathrm{~m}^{3}$ (ili za područje veće od 20 hektara) potrebna E.I.A. (Procjena utjecaja na okoliš). **: projekt je podvrgnut E.I.A. usmjerenoj više na gospodarenje otpadom (kriteriji smještanja, vrste otpada, tretmani, barijere za buku i prašinu...). Strelice usmjerene od dna prema vrhu naglašavaju da postupak dobivanja dozvole, koncesije ili autorizacije započinje od strane tvrtki za eksploataciju: zahtjevi trebaju biti u skladu s instrumentima koje donose planovi i sa samim planovima (npr. smještaj). Općine primaju zahtjeve za eksploataciju i predaju ih Službi za rudarstvo koja saziva interdisciplinarni odbor. Za materijal prve kategorije tvrtke trebaju svoje projekte predstaviti na razini pokrajine (Služba za rudarstvo), a zainteresirane općine su uključene u proces donošenja odluke. 


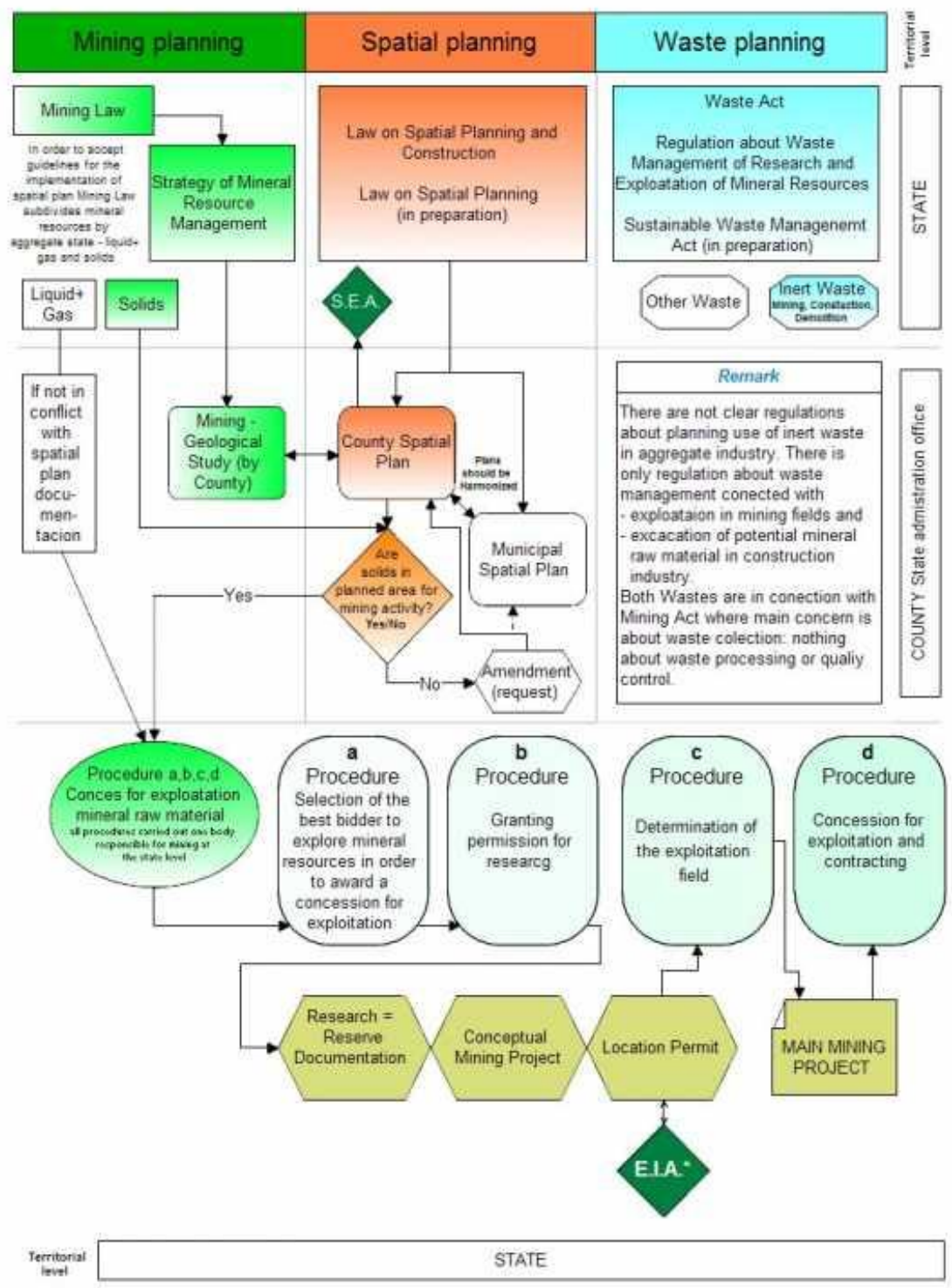

Slika 3 - Shema prostornog planiranja i njegova interakcija sa zakonima o rudarstvu i budućim Zakonom o upravljanju otpadom u Hrvatskoj. *: Procjena utjecaja na okoliš u Hrvatskoj je obavezna za sve pothvate u rudarskoj industriji. 


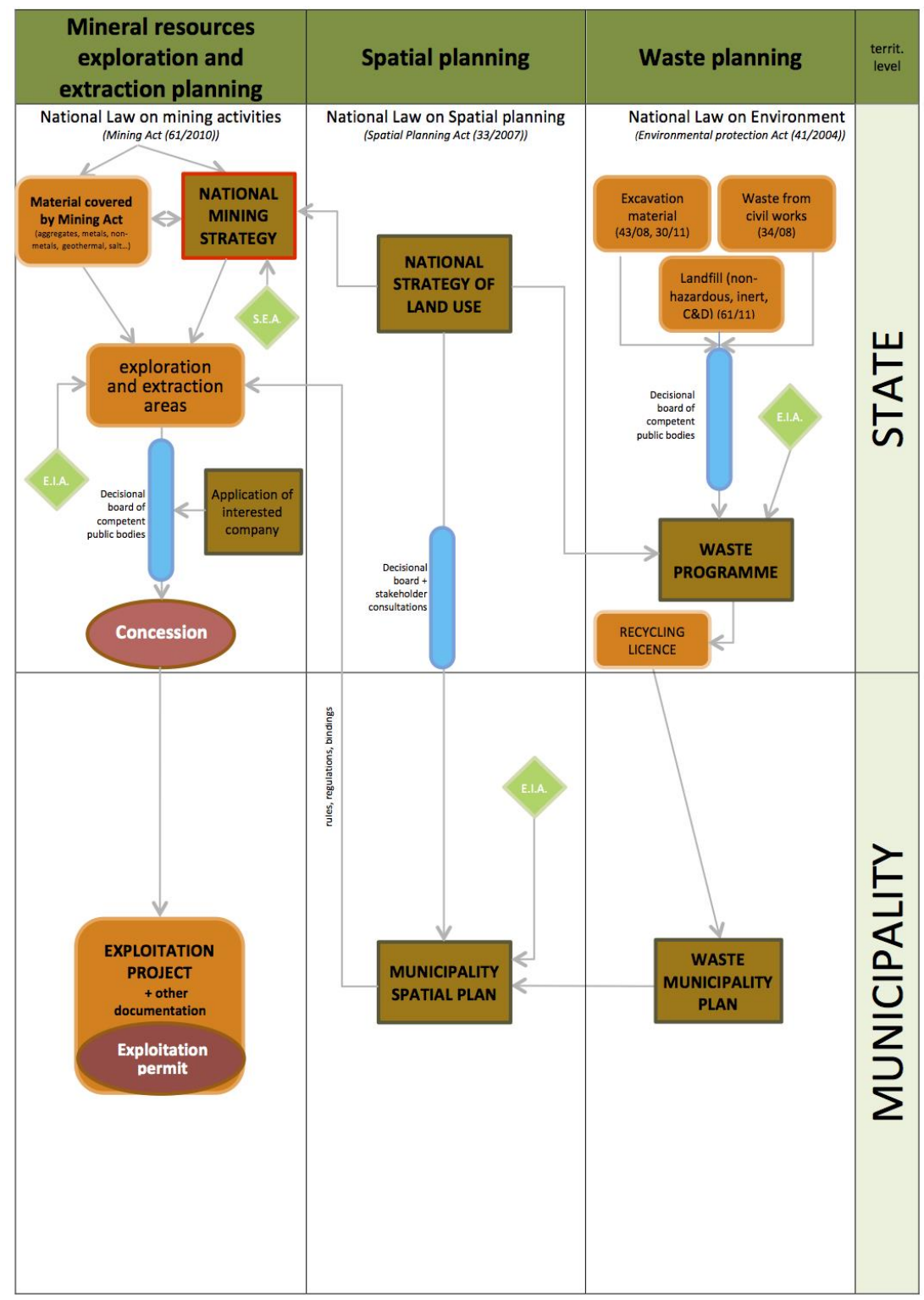

Slika 4 - Shema planiranja vezana za agregate, otpad i njihovu interakciju s prostornim planiranjem u Sloveniji. 


\subsection{Centralizirani ili decentralizirani pristup?}

Iskustvo u jugoistočnoj Europi pokazuje da mnoge zemlje delegiraju provedbu svojih politika mineralnih sirovina nižim nivoima vlasti. U mnogim zemljama, ključnu ulogu prilikom izdavanja dozvola imaju općinske vlasti, iako njihova uloga u razvoju plana nije jasna ili nije definirana.

Mnoge zemlje slijede centralizirani pristup, između ostalih i Albanija, Slovenija i Srbija. Centralizirani pristup ima mnoge prednosti, uključujući i lakoću izrade koherentne nacionalne strategije bez rizika od nedostatka harmonizacije među administrativnim tijelima nižeg reda. Druga prednost je pojednostavljenost postupka izdavanja dozvola koju daje jedno nadležno tijelo.

Primjera radi, u Albaniji se provodi plan djelovanja za primjenu rudarske strategije, a opisan je u državnom Zakonu o rudarstvu (slika 5). Plan djelovanja definira primjenu srednjoročne strategije iz dokumenta za planiranje mineralnih sirovina, a on se priprema na temelju rudarske strategije i važeći je za period od 3 godine.

Plan djelovanja uključuje:

- Smjernice za razvoj rudarskog sektora;

- Promociju rudarskih područja za koja će se dozvole za eksploataciju dodjeljivati putem javnog natječaja;

- Promociju rudarskih područja koja se temelje na digitalnoj karti koja se izrađuje u roku od godinu dana od stupanja ovog zakona na snagu, a zatim se neprekidno ažurira;

- Programsko uređenje osnovnih aktivnosti geološkog istraživanja;

- Predviđanje ukupnog godišnjeg proizvoda u rudarskom sektoru;

- Osposobljavanje za rudarske djelatnosti;

- Pravila provedbe sigurnosnih mjera i sigurnosti zaposlenika;

- Propise vezane uz zaštitu okoliša, uređenje okoliša i sanaciju;

- Rizična područja, u kojima je zabranjena eksploatacija i za koja se ne smiju odobravati prava na eksploataciju mineralnih sirovina;

- Tablice s minimalnim vrijednostima za određenu površinu za koju se izdaje dozvola za eksploataciju, minimalnim vrijednostima ulaganja koje omogućavaju dobivanje dozvole za istraživanje i otkrivanje mineralnih rezervi i za njihovu eksploataciju, kao i minimalnim vrijednostima za 
dobivanje dozvole za proizvodnju i eksploataciju za oblasti koje se stavljaju na javni natječaj, prema grupama mineralnih sirovina.

U Albaniji (slika 5), određivanje područja i kriterija za utvrđivanje minimalne veličine, minimalne vrijednosti ulaganja i minimalne vrijednosti proizvodnje obavlja Ministarstvo, a usvaja Vijeće ministara. Kao mjera primjene plana djelovanja usvojen je Godišnji plan eksploatacije koji uključuje definiranje rudarskih područja za koja se u toj godini mogu dodijeliti dozvole za eksploataciju. Godišnji plan izrađuju tijela nadležna za rudarstvo, a odobrava ga ministar nakon procesa savjetovanja na centralnoj razini (s nadležnim ministarstvima kao što su Ministarstvo okoliša; Ministarstvo turizma; Ministarstvo transporta; Ministarstvo poljoprivrede; Ministarstvo obrane) i savjetovanja s nadležnim tijelima lokalne vlasti na lokalnoj razini. Sve izmjene i amandmani u postojećem godišnjem planu usvajaju se i objavljuju istim postupkom.

Centraliziran pristup u velikim državama može otežati uključenost lokalnih zajednica tijekom izrade plana i obično podrazumijeva vođenje računa o razlikama u dostupnosti primarnih i sekundarnih agregata i različitim nivoima razvijenosti (pa samim tim i različitom potražnjom) u različitim dijelovima zemlje. 


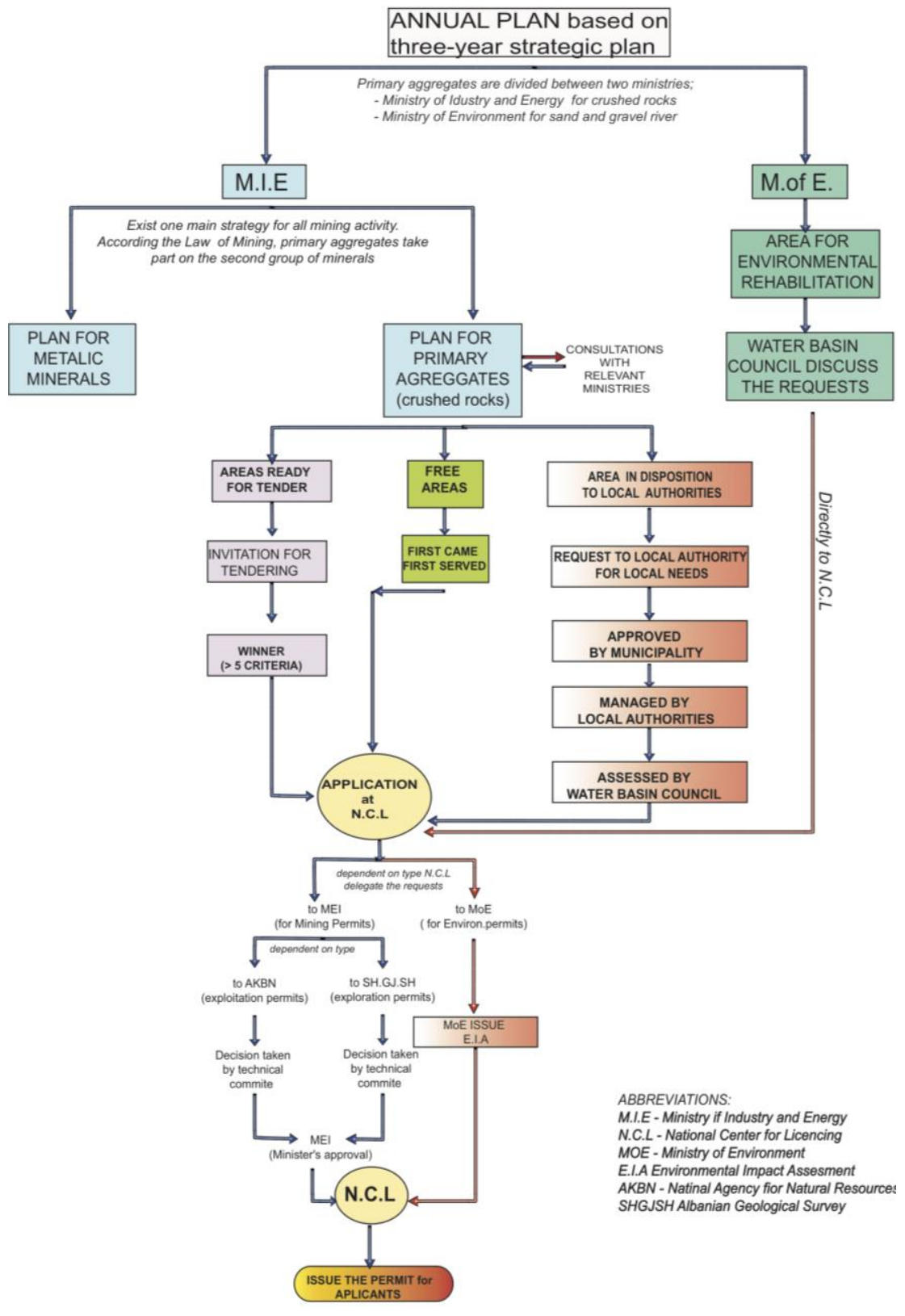

Slika 5 - Shema rudarskog plana i postupaka za dobivanje dozvola u Albaniji. AKBN: nacionalna agencija za prirodne resurse; SHGLSH: Albanska geološka služba. 
Veće zemlje imaju složeniji međusobni odnos između državnih i lokalnih planova: Brojni primjeri uključuju i Italiju (slika 6), Grčku (slika 7), Mađarsku (slika 8) i Austriju. U Italiji je planiranje korištenja prostora dodijeljeno prvostupanjskim administrativnim tijelima (regijama); one zatim imaju mogućnost neke od administrativnih funkcija dodijeliti drugostupanjskim administrativnim tijelima (pokrajinama). Takav je slučaj i u Regiji Emilia-Romagna u kojoj je 1991. godine izrada rudarskih planova delegirana pokrajinskim vlastima radi poticanja decentralizacije i zajedničkog gospodarenja javnim resursima Regija Emilia-Romagna pritom zadržava centralnu koordinacijsku ulogu, a pokrajinski rudarski plan uzima u obzir informacije, pravila, obaveze i propise koji potječu iz drugih regionalnih i pokrajinskih prostornih planova i izvora podataka. Regija pruža informacije o geološkim resursima, odobrava plan i vodi registar područja pogodnih za eksploataciju.

Odbor sastavljen od nadležnih državnih tijela i dionika pokreće proces kojim se izrađuje Pokrajinski rudarski plan (uglavnom definiran kao rudarski plan za šire područje), a potvrđuje ga Odbor za Stratešku procjenu životne sredine. Pokrajinski rudarski plan sadrži:

a) Kvantifikaciju potreba za mineralnim sirovinama za period od deset godina, na skali nižoj od regionalne;

b) Identifikaciju pokrajinskih udruženja za eksploataciju agregata i definiciju kriterija i smjernica za lokacije na kojima će se vršiti eksploatacija, a koje su od značaja za općine, na temelju postojećih resursa (kako je kvantificirano u prvoj stavci [a]), fizičkim i krajobraznim faktorima i potrebama za poljoprivrednim površinama i razinama podzemnih voda;

c) Kriterije i metode za rekultivaciju i konačnu oporabu novih, kao i za oporabu već napuštenih kamenoloma;

d) Kriterije za korištenje i/ili obnovu zatvorenih kamenoloma za javnu uporabu.

Plan je propraćen studijom ekološke ravnoteže koja potvrđuje kompatibilnost eksploatacije s okolišem na temelju važećeg zakona. Studija ekološke ravnoteže sadrži identifikaciju područja s visokom ekološkom osjetljivošću te razloge za njihov odabir u odnosu na moguće alternative. Pokrajinski rudarski plan vrijedi deset godina, nakon čega se mora revidirati, ažurirati i usvojiti na nivou općine u roku od dvije godine od njegovog prihvaćanja. Općinski rudarski planovi daju detaljniji prikaz okvira definiranog pokrajinskim planom. Ovi planovi, u konačnici, utvrđuju područja pogodna za eksploataciju od strane privatnih osoba; daju procjenu utjecaja na okoliš, mjere za smanjenje očekivanih negativnih utjecaja, kao i plan oporabe. Regionalne službe zadužene su za provjeru i reguliranje tehničke usklađenosti pokrajinskog 
rudarskog plana $s$ pokrajinskim prostornim planom te regionalnim planovima i pravilima, što ponekad zahtijeva određene promjene.

Slično tomu, javna odgovornost u Austriji je podijeljena na četiri nivoa nadležnosti u saveznoj strukturi - Saveznu vladu, savezne države (Länder), okruge i općine. Savezna vlada, točnije Ministarstvo gospodarstva, obitelji i mladeži, snosi odgovornost za ukupnu politiku mineralnih sirovina, ali je zato prostorno planiranje u nadležnosti saveznih država.

Posljedica toga je da svaka od devet saveznih država ima vlastite zakone za regionalno planiranje koji su u prošlosti imali različite odredbe u pogledu zaštite mineralnih sirovina. Kako je rad na Planu mineralnih sirovina odmicao, i to uz pomoć savezne vlade, većina ovih država razvila je sektorske regionalne razvojne planove za sirovine i definirala „zone pogodne za eksploataciju“ $\mathrm{i}$ „područja za zaštitu mineralnih sirovina“. Naravno, prilikom planiranja na nivou pojedine savezne države, neophodno je uzeti u obzir lokalne interese i specifičnosti. Nadalje, prema Aktu o mineralnim nalazištima, br. 33, usvojenom 1947. godine, Zavod za geološka istraživanja i tijela nadležna za rudarstvo obvezni su surađivati prilikom svakog istraživanja mineralnih sirovina u tom području. Dugoročna i konstruktivna suradnja nastala na temelju ove obaveze pokazala se kao odličan temelj za dobivanje visoko-kvalitetnih informacija koje se odnose na mineralne sirovine.

Iz ovih se primjera vidi kako centralizirano planiranje odražava državnu organizaciju prostornog planiranja. Ovaj model je poželjan onda kad je površina države značajno manja od $100.000 \mathrm{~km}^{2}$, jer tad dopušta kompletnu preglednost svih resursa agregata i točnija predviđanja. Postoje i mnogi slučajevi gdje je priroda plana već određena državnim zakonodavstvom ili postoji potreba za planom koji se posebno izrađuje za određeni teritorij kako bi se više pažnje posvetilo regionalnim problemima (kao primjer usporediti shemu planiranja u Federaciji Bosne i Hercegovine, slika 9).

\subsection{O složenosti izrade plana za mineralne sirovine}

Planiranje agregatnih resursa obično je dio općeg plana vezanog za mineralne resurse: Austrijski plan mineralnih sirovina je više puta naveden kao primjer najbolje prakse u planiranju korištenja prostora na razini Europe. Različite odlike ovog plana, uključujući sistematični pristup po kojem je izrađen, predstavljaju primjere dobre prakse, a nedavno su dane i dodatne pojedinosti o njegovoj primjeni na lokalnoj razini (CSES, 2014). 


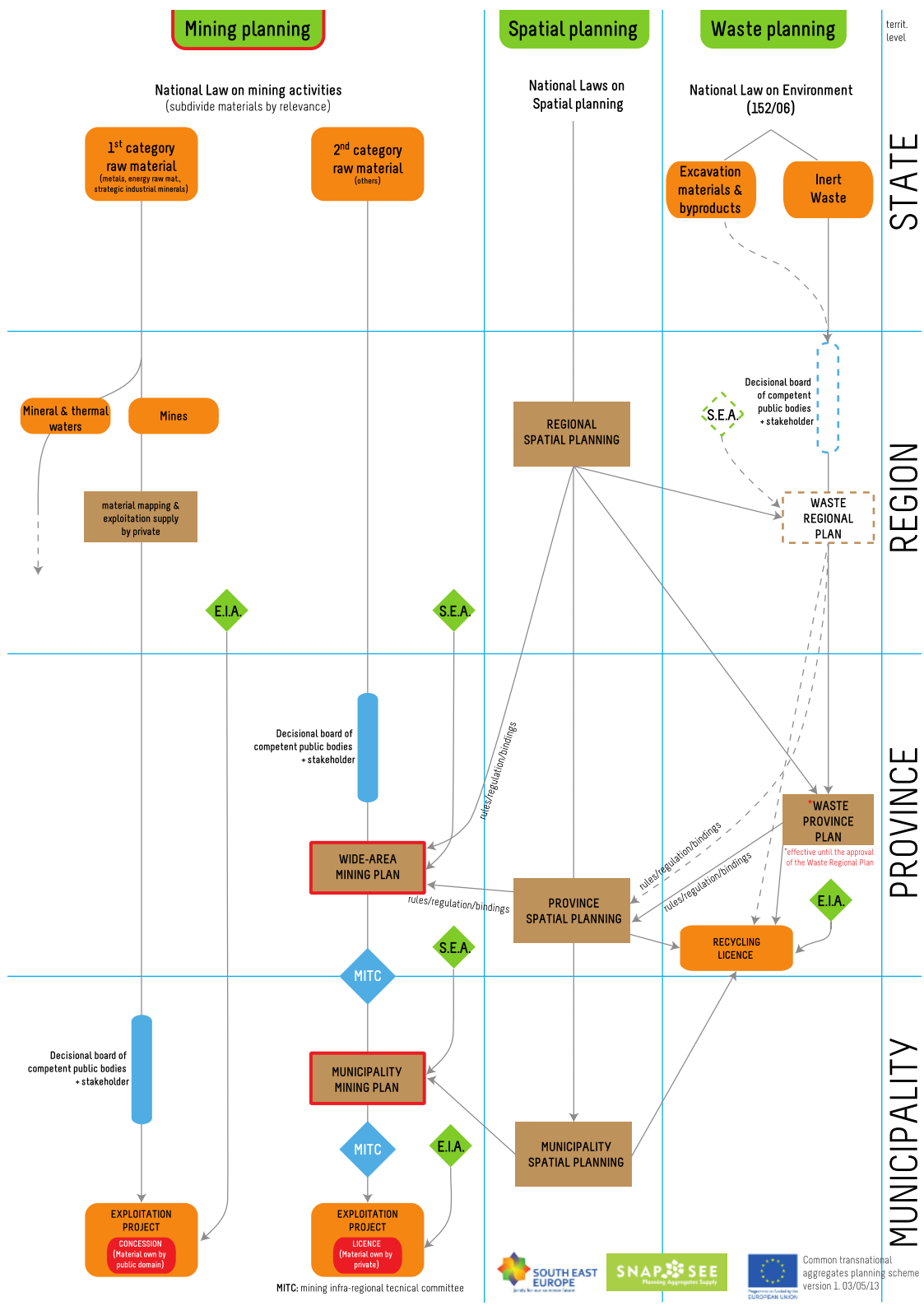

Slika 6 - Shema Regionalnog planiranja vezana uz opskrbu agregatima:

Primjer Regije Emilia-Romagna u Italiji. 


\section{Planning Scheme of Aggregates in Greece (2014)}

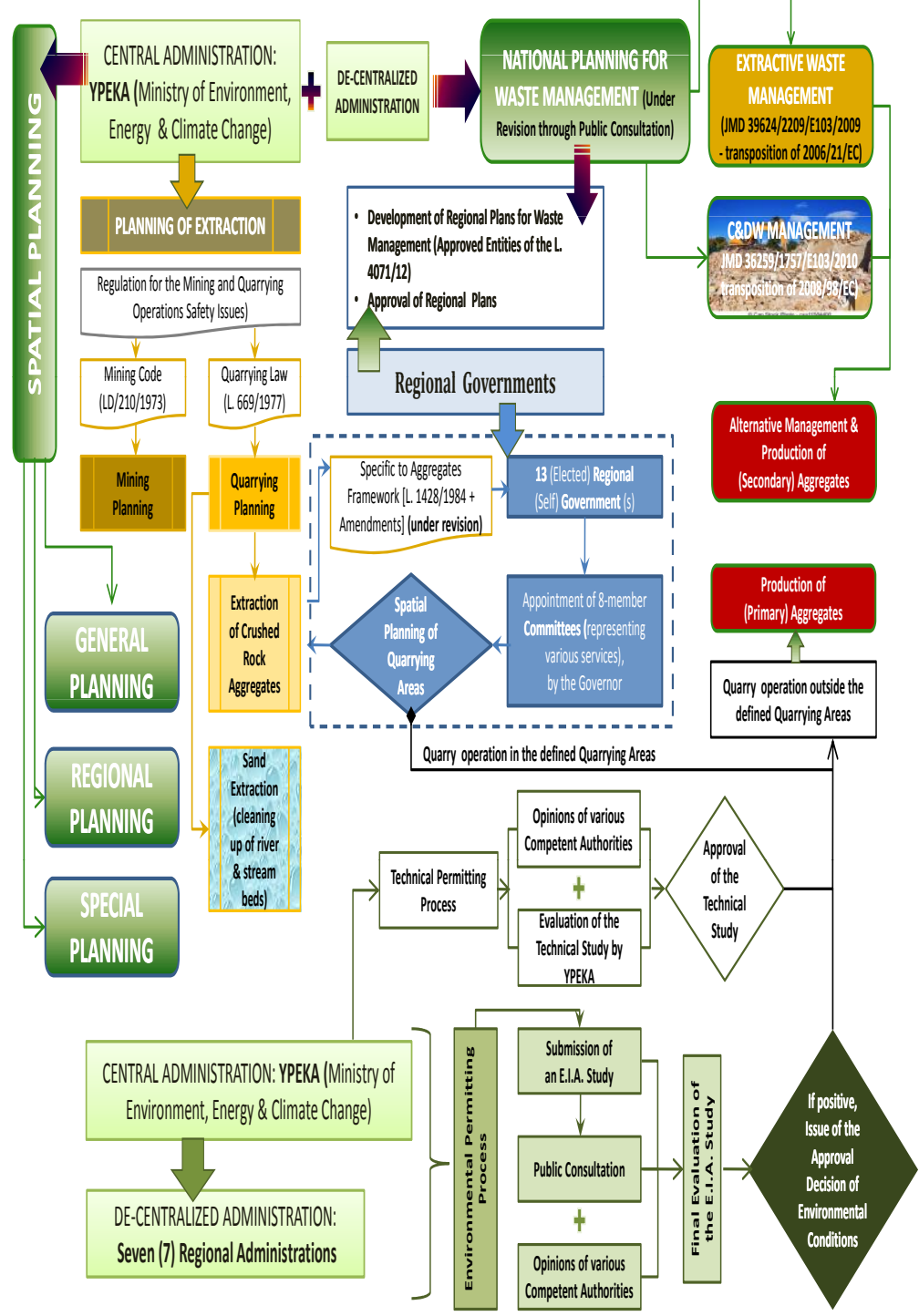

Slika 7-Shema planiranja gospodarenja agregatima u Grčkoj 


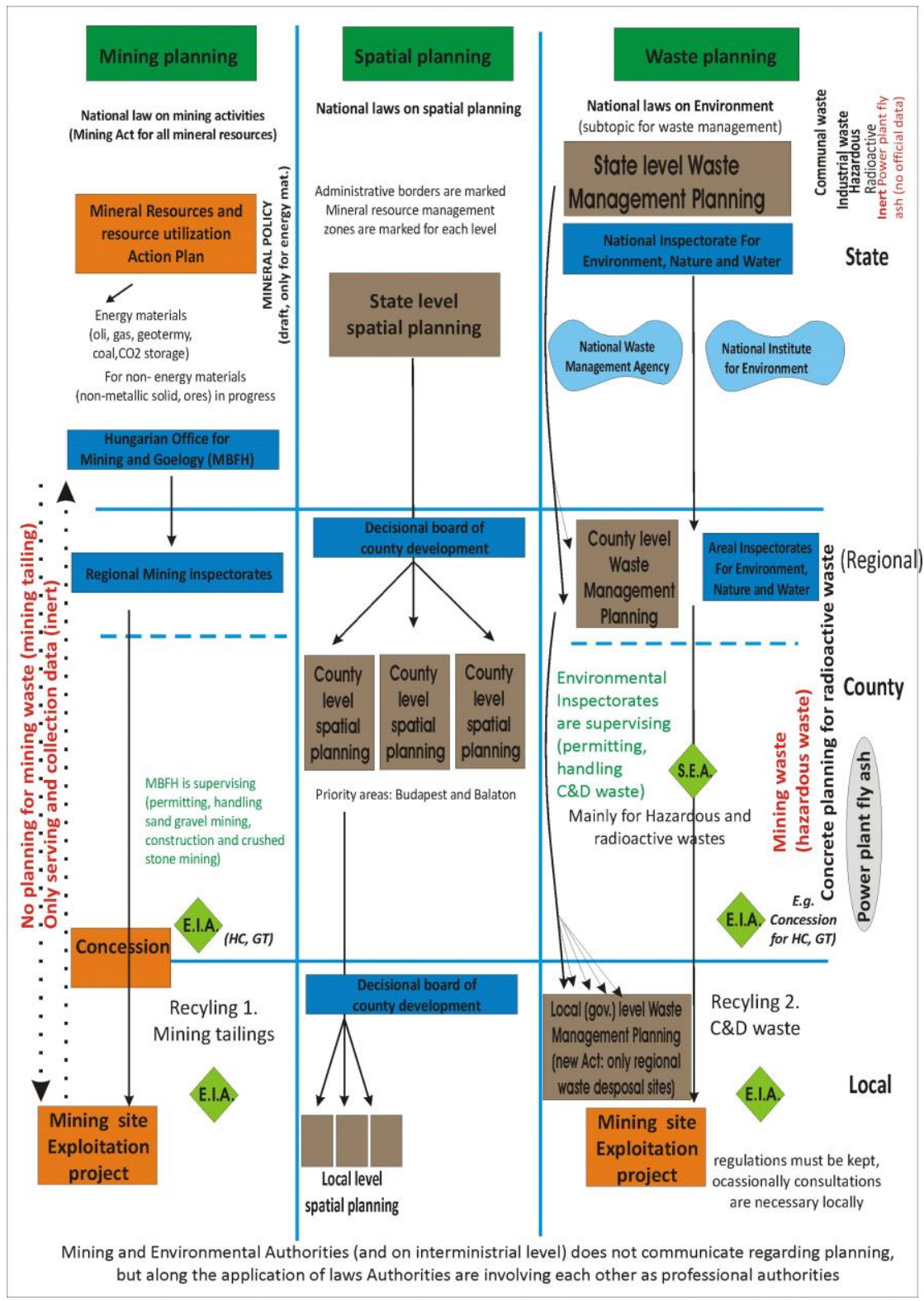

Slika 8 -Mađarski model planiranja rudarstva, korištenja prostora i gospodarenja otpadom 


\section{Aggregates planning scheme in Bosnia and Herzegovina}

and Herzegbosnian canton

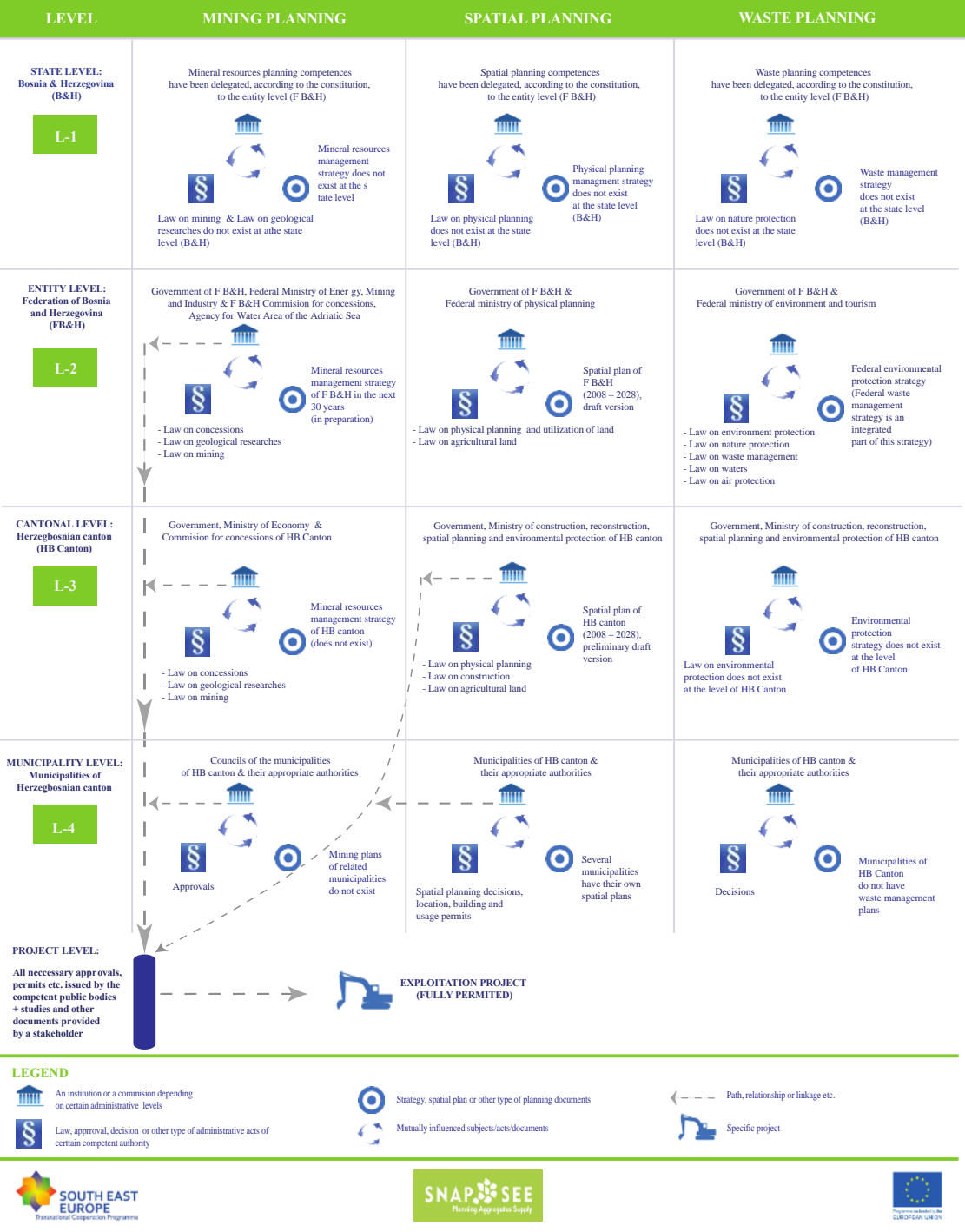

Slika 9-Planiranje opskrbe agregatima na različitim upravnim razinama u Federaciji Bosne i Hercegovine i Kantonu 10. 
Prva lekcija koja se može naučiti iz austrijskog iskustva je ta da izrada plana može dugo trajati, jer zahtjeva točnu i objektivnu sintezu dostupnih podataka o prostornom rasporedu mineralnih sirovina, precizno kartiranje dostupnih resursa, kao i analizu njihovih konflikata s drugim strategijama korištenja prostora. Cilj prvog pristupa je, dakle, odrediti područja bez konflikta. Ona ležišta mineralnih sirovina za koje se dokaže da zaslužuju biti pod zaštitom zbog svoje kvalitete, kvantitete i nepoklapanja sa „zabranjenim“ ili konfliktnim zonama, predana su u nadležnost tijelima vlasti pokrajina koja ih proglašavaju područjima za zaštitu mineralnih sirovina tijekom planiranja korištenja prostora. Poštivanje metoda zaštite mineralnih sirovina u planiranju korištenja prostora omogućilo je da se pijesak i šljunak sačuvaju i budu dostupni idućih 50 godina, a tehničko-građevni kamen sljedećih 100 godina za većinu regija opskrbe (Weber i dr. 2012).

Bilo je potrebno gotovo deset godina da se Austrijski plan mineralnih sirovina završi. Proces je započeo usvajanjem amandmana na Zakon o mineralnim sirovinama 2001. godine, a završio se 2012. godine publiciranjem dokumenta (Der Österreichische Rohstoffplan - Weber i dr. 2012). Svrha plana je postavljanje temelja u pripremi za daljnje aktivnosti koje obavljaju privatne tvrtke.

\subsection{Strategija EU}

Studije i rasprava koje su potaknuli projekti SARMa i SNAP-SEE ukazali su na to u kolikoj mjeri razvoj državnih politika može dovesti do raslojavanja i nehomogenosti te uslijed različitosti u zakonodavnom okviru izaziva međudržavne probleme. U današnje vrijeme i dalje postoji previše razlika među politikama mineralnih sirovina i planovima na različitim političkim razinama širom regije. Europska Unija bi trebala progresivno integrirati i homogenizirati državne politike i planove definiranjem zajedničkih strategija: treba napomenuti da su resursi agregata, koji se smatraju jednom od sirovina koju treba osigurati i generacijama koje dolaze, obuhvaćeni strategijom „Europa 2020”.

lako nisu sve zemlje jugoistočne Europe članice EU, principi koje postavlja stup strategije EU2020, a koji se odnosi na efikasnost resursa, predstavlja obavezan cilj za cijelu regiju, imajući u vidu neobnovljivu prirodu primarnih agregata, ali i zbog utjecaja koji eksploatacija i odlaganje inertnog otpada imaju na životnu sredinu i društvo. 


\section{Smjernice za planiranje}

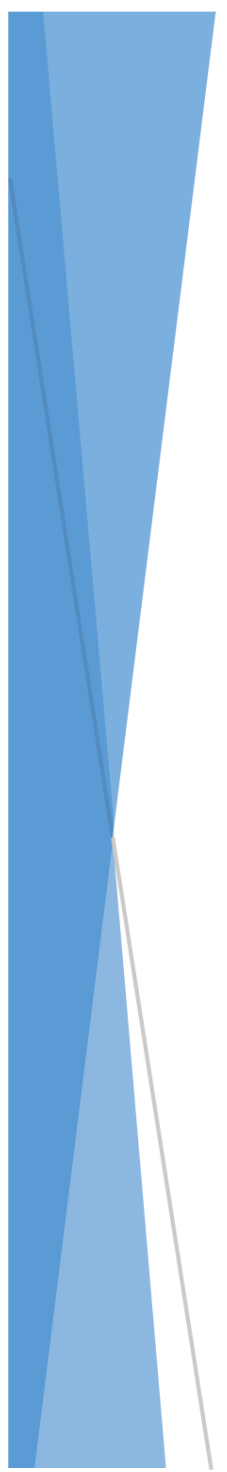

Izrada plana treba započeti strategijom na državnom nivou $i$ mora pratiti obveze definirane državnim zakonima.

Postupak koji treba slijediti prilikom pripreme plana obično je podložan izmjenama kako bi ga se moglo prilagoditi za svaki pojedini sektor. Eksploatacija mineralnih sirovina, uključujući prirodne agregate, može imati loše utjecaje na zemlju $i$ zahtijeva uravnoteženu uključenost dionika kako bi se ukazalo na potrebe $i$ prednosti održivog pristupa. Izrada strateškog plana zahtijeva da se vrijednosti i prioriteti razmotre $i$ jasno iznesu; plan bi trebao odražavati stavove svih strana koje su uključene u proces. Zemlje koje su uspješno izradile i usvojile planove uključile su sve zainteresirane strane $u$ proces strateškog planiranja. 


\subsection{Faze razvoja plana}

\subsubsection{Prva faza: preliminarni dokument}

Prvi korak u razvoju plana je analiza uloge tijela u čijoj je nadležnosti sama izrada plana, kao i njegovih ciljeva (slika 10). Traženje odgovora na pitanje „Što je to s čim trebamo raditi?" podrazumijeva razmatranje jakih i slabih strana tijela nadležnog za planiranje agregata, kao i odlučnost da se iz jakih strana izvuče njihov maksimum. U ovoj fazi bilo bi korisno pročitati „Posebne karakteristike planiranja opskrbe agregatima“ iz Horváth i dr. (2014), poglavlje 1.2.

Drugi korak je definiranje vizije. Horváth i dr. (2014) se posebno bave ovim aspektom planiranja u 4. dijelu priručnika "Zajednička vizija optimalnog sadržaja plana za agregate", u kojem iznose dobar primjer vizije na nivou Jl Europe koja se također može usvojiti i na državnom nivou. S obzirom da se izražena vizija temelji na mišljenju svih sudionika u procesu, neophodno je tijekom realizacije ovog koraka uključiti sve one koji će imati svoj udio u postizanju vizije.

Treći korak predstavlja artikuliranje ciljeva definiranih vizijom. Ovih ciljeva može biti više, poput gospodarskog rasta, obilne opskrbe sirovinama i zaštite okoliša, a oni međusobno mogu biti i sukobljeni,. Za svaki od ovih ciljeva, planeri moraju navesti sredstva za njihovo postizanje. Ovaj korak podrazumijeva artikuliranje strategija za postizanje rezultata. Strategije trebaju odražavati snage i slabosti tijela uključenog u planiranje kako ne bi bile ograničene, npr., nedostatkom podataka ili sposobnošću provedbe plana u budućnosti.

Četvrti korak je definiranje okvira znanja koji služi kao potpora strategijama

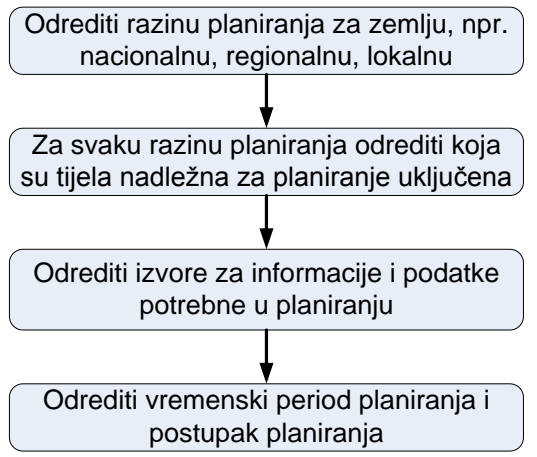

Slika 10 Prvi koraci u izradi rudarskog plana, prema Agioutantis i dr. (2014). 
utvrđenim u trećem koraku. Podaci su ključan element održivog plana. Bez podataka plan ne može dati predviđanja i ne može se ažurirati u skladu $s$ promjenama $u$ potražnji. Ukoliko se podaci ne prikupljaju redovito, to treba promijeniti, a plan treba sadržavati procjenu potrebe za takvim podacima. $S$ obzirom da plan treba definirati neke metode kojima se mjeri stupanj postignutosti cilja, podaci su i ključni aspekti u praćenju i evaluaciji alternativnih scenarija. Za potpun pregled ovog koraka, uključujući i uvid u analizu životnog ciklusa kao alata za evaluaciju potencijalnih scenarija, pozivamo čitaoca da pročita Agioutantis i dr. (2014), koji je sastavni dio ovog Alatnog okvira.

\subsubsection{Druga faza: Razmjena podataka}

Dionici se trebaju uključiti u ranoj fazi izrade plana (slika 11). Smjernice o organiziranju uključenosti dionika mogu se pogledati u Dolinar i dr. (2014), uključenom u Alatni okvir. Dionici moraju biti obrazovani i osposobljeni za rad sa složenim međuodnosima prirodnih, gospodarskih i socijalnih pitanja vezanih uz opskrbu primarnim i sekundarnim agregatima: stoga je važno održavanje informativnih sastanaka i radionica kako bi se dionici upoznali s problematikom.

Plan zatim treba razvijati procesom učestalih aktivnosti kako bi se razriješili eventualni konflikti između zainteresiranih strana i ciljeva. Hijerarhijska raspodjela ciljeva može biti od pomoći u ovom slučaju, a njihov popis treba biti jasan i sažet kako službe i industrija ne bi bili zatrpani s previše detalja vezanih uz prikupljanje podataka i izvješćivanje.

Državni službenici i rukovoditelji javnih programa u ovoj fazi često moraju balansirati između sukobljenih nadležnosti i ciljeva prilikom formuliranja strateških planova. U takvim slučajevima zakonodavni akti mogu biti sastavljeni uz konzultacije s većim brojem predstavnika čiji su stavovi sukobljeni. Razvijajući strateške planove, javni rukovoditelji bi trebali prepoznati da programi možda imaju oprečne smjernice te se izjasniti o tome što agenciju mogu, a što ne mogu, u tom pogledu učiniti.

\subsubsection{Treća faza: Odobrenje}

Nakon završetka konzultacija s dionicima, treba finalizirati dokument plana. Tijela vlasti imenovana kao nadležna za izradu plana trebaju uzeti u obzir sugestije i strategije za rješavanje konflikata proizašlih iz prethodne faze. Konačni dokument trebao bi detaljno opisati sve aspekte postupaka za izdavanje dozvola, interakcije između državnih/regionalnih planova i planova na razini općina, kao i upute za praćenje rezultata samog plana.

Pripremljen konačni dokument treba poslati svim uključenim dionicima kako bi iznijeli svoje primjedbe, koje mogu biti usvojene ili odbijene u zavisnosti od izabrane 
strategije, a nakon toga političkom odboru koji će ga usvojiti i proglasiti važećim. Ovako napravljen plan eksploatacije mora se revidirati i ažurirati, a mora ga prihvatiti široki odbor dionika.

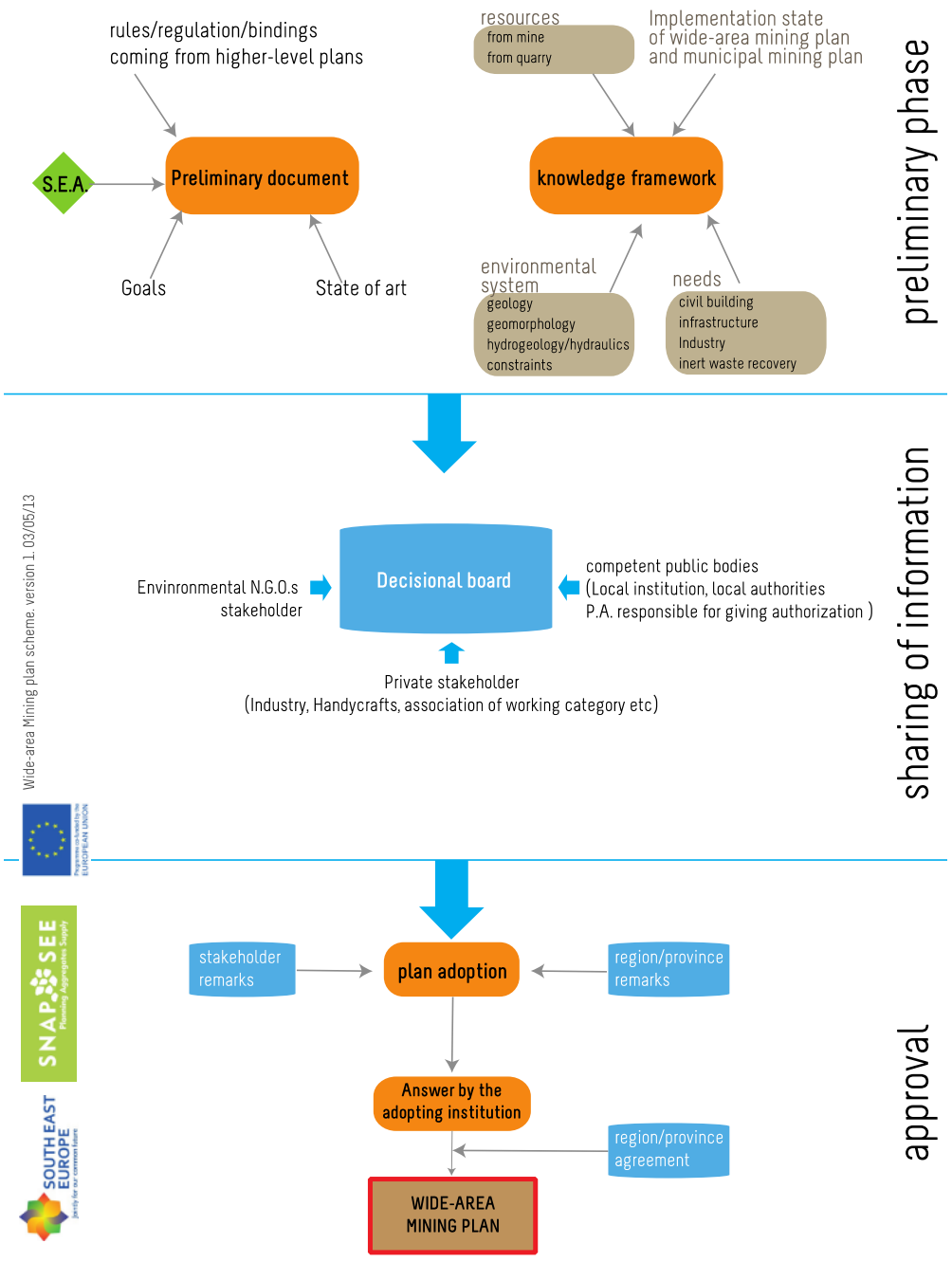

Slika 11 - Opća shema planiranja 


\subsection{Struktura plana}

Proces izrade plana mora biti reguliran državnim zakonima.

Osim toga, ukoliko već nije utvrđeno postojećim zakonima, odluka kojom se plan proglašava važećim treba:

- Utvrditi potrebu za (državnim) planom za agregate;

- Utvrditi potrebu za integracijom plana za agregate u opći prostorni plan;

- Koordinirati plan za agregate s planom gospodarenja otpadom;

- Utvrditi vlasništvo nad primarnim agregatima.

Proces izrade plana treba voditi odbor sastavljen od nadležnih javnih tijela i dionika i treba biti ovjeren putem Strateške procjene utjecaja na okoliš.

Kako bi se postigao održiv pristup, plan treba sadržavati:

- Internu dosljednost s principima koji su prihvaćeni na europskom nivou, kako bi se osigurala progresivna homogenizacija čitave regije;

- Brojčano izraženu potrebu za različitim mineralnim sirovinama na duži rok (u idealnom slučaju na više od deset godina);

- Identifikaciju područja optimalnih za eksploataciju i zaštitu agregata;

- Identifikaciju alternativnih izvora, procjenu njihovih doprinosa smanjenju potrošnje prirodnih resursa i njihovu lokaciju, s ciljem smanjenja troškova transporta i negativnih utjecaja na okoliš;

- Definiciju kriterija i smjernica za lokacije rudarskih područja koja su od značaja za općine;

- Uvjerenje o konkurentnosti u industriji agregata;

- Kriterije i metode za održavanje BATs-a (Best Available Technologies najbolja dostupna tehnologija), obnovu novih kamenoloma, kao i za obnovu napuštenih kamenoloma;

- Kriterije za korištenje prostora nakon zatvaranja kamenoloma i, gdje je moguće, vraćanje prirodi i/ili komercijalnoj upotrebi; 
- Uspostavu koordinacije između tijela nadležnih za izdavanje dozvola i tijela zaduženih za prostorno planiranje;

- Uspostavu učinkovite i djelotvorne procedure za izdavanje dozvola;

- Studiju ekološke ravnoteže koja potvrđuje da je prema trenutno važećoj pravnoj regulativi eksploatacija kompatibilna s okolišem.

Na idućim stranicama o svakoj od ovih stavki raspravljat će se u detalje, a bit će dani i primjeri određenih tekstualnih modula. Svrha tekstualnih modula je pružiti formulaciju koja se može koristiti od riječi do riječi od strane vlasti, dok razvijaju ili revidiraju svoje planove za agregate. Tekst predstavlja sintezu formulacija najboljih praksi planiranja korištenih u planovima za agregate unutar i izvan Europe. Za kompletno obrazloženje svakog od elemenata može biti od koristi da se uz čitanje konzultiraju i rezultati koji su predstavljeni u Horváth i dr. (2014) u odnosu na „Viziju najboljih praksi za održivo planiranje agregata“.

\subsubsection{Utvrđivanje potrebe za državnim planom za kamene agregate}

Državni plan za agregatne resurse neophodan je kako bi se osigurala održiva opskrba agregatima tijekom generacija.

Državna politika mineralnih sirovina (agregata) može se definirati kao sve radnje kojima država utječe na opskrbu i potražnju za mineralnim sirovinama na svom teritoriju.

Državna politika mineralnih sirovina treba najprije razviti svijest o potrebama društva za mineralnim sirovinama, a posebno za kamenim agregatima, te u slučaju kamenih agregata o potrebama pristupa lokanim resursima. Drugi ključni problem je da opskrbu mineralnim sirovinama, a posebno kamenim agregatima, treba postaviti kao prioritet za dobrobit društva te uspostaviti uravnotežen pristup u procjeni istraživanja i razvoja eksploatacije. (Tiess 2010, UEPG 2010).

- U svakoj bi zemlji trebala postojati najmanje dva nivoa planiranja. Viši nivo, ovdje nazvan "državni plan“ odnosi se na plan koji rukovodi aktivnostima na području od najmanje 20-50 tisuća $\mathrm{km}^{2}$ ili 2-5 milijuna stanovnika. Drugi nivo planiranja, obično na razini jedne općine, treba osigurati optimalno iskorištenje prostora i društvenu prihvatljivost, a treba se oslanjati na opće planove kako bi se osigurala održivost opskrbe agregatima u zemlji.

- Plan za agregatne resurse može biti dio općeg plana mineralnih sirovina. 


\subsubsection{Uklapanje plana za kamene agregate u opći plan korištenja prostora}

Plan mineralnih sirovina plan i plan za agregate treba uklopiti u opći plan korištenja prostora (prostorni plan) kako bi se osigurao pristup resursima kamenih agregata, čak i tamo gdje su konkurentni oblici korištenja mogući.

Ovaj zahtjev treba direktno ispuniti zakonodavstvo za prostorno planiranje, a zatim ga treba preuzeti plan mineralnih sirovina.

\subsubsection{Utvrđivanje vlasništva nad primarnim agregatima}

Vlasništvo nad primarnim agregatima u JI Europi u nekim slučajevima pripada državi, a u drugim zemljama vlasniku zemljišta. Ipak, sigurna i dostatna opskrba mineralnim sirovinama je osnovna zadaća rudarske industrije, iako se često dopušta eksploatacija za privatne potrebe (tj. ne u komercijalne svrhe).

Kako bi se osiguralo pravo na eksploataciju, a time da se u planu lako prepoznaju moguće rudarske zone, vlasništvo nad primarnim agregatima trebalo bi pripadati državi ili njenim delegatima (Hamor, 2012). Treba, međutim, spomenuti da nije moguće natjerati državu da promijeni sve propise kako bi se prenijelo vlasništvo, npr. s vlasnika zemljišta na državu, budući da se vlasništvo nad sirovinama (pa i agregatima) temelji na suverenom državnom zakonodavstvu i ne može se promijeniti sektorskim planom (ili zakonima EU). Kad se vlasništvo nad agregatima mora priznati vlasniku zemljišta, treba zatražiti posebno odobrenje za eksploataciju, a proces odobrenja treba poštivati prioritetna područja koja su označena planom.

\section{Primjer tekstnog modula 1:}

Izvorno vlasništvo nad resursima primarnih agregata pripada lokalnoj upravi (državi, pokrajini, okrugu, općini). Privatnom investitoru može putem javne nabave biti odobrena dozvola za eksploataciju na određenom području.

\section{Primjer tekstnog modula 2:}

Izvorno vlasništvo nad resursima primarnih agregata pripada zemljoposjedniku s obzirom da su primarni agregati svrstani u grupu materijala koji se eksploatiraju u kamenolomima. Kako bi dobio dozvolu za eksploataciju primarnih agregata, vlasnik treba zatražiti posebno odobrenje zbog ravnoteže između potreba proizvodnje $i$ zaštite okoliša. Ovaj zahtjev se odnosi i na slučaj kad vlasnik zemljišta želi osobno eksploatirati agregate iz budućeg kamenoloma, i na slučaj da područje iznajmi trećoj strani za eksploataciju. 


\subsubsection{Pozivanje na načela dogovorena na nivou Europe}

Procedure za definiranje sektorskog plana odražavaju, prije svega, zakonodavni okvir zemlje.

S obzirom na državnu autonomiju i povijesne razloge koji dovode do različitih pristupa u razvoju mineralnih politika u zemljama JI Europe, budući planovi za održivo gospodarenje kamenim agregatima trebali bi uzeti u obzir i po mogućnosti se usmjeriti prema strategiji EU2020, jer se njeni glavni zadaci mogu smatrati minimalnim zajedničkim ciljevima u održivom razvoju.

U mnogim zemljama EU, regionalne ili lokalne vlasti su nadležne za politička područja vezana uz strategiju Europa 2020. Od ključnog je značaja da sve razine vlasti budu svjesne potrebe da se na terenu djelotvorno sprovede strategija EU2020 kako bi se postigao pametan, uključiv i održiv gospodarski rast te da svatko odigra svoju ulogu u uvođenju neophodnih promjena.

\section{EU regulativa koju treba uzeti u obzir:}

- Okvirna direktiva o otpadu 2008/98/EC i odluka Komisije o njenom provođenju

- Direktiva 89/106/EEC o približavanju zakona, propisa i administrativnih odredbi Država članica u pogledu građevinskih proizvoda (izmijenjena $\mathrm{i}$ dopunjena Direktivom 93/68/EEC)

- Priopćenje Europske komisije u okviru provođenja Direktive 89/106/EEC (2010/C 167/01) daje 11 različitih CEN standarda koji se tiču agregata

- Europski katalog otpada

- Odluka Suda pravde (C-114 slučaj Avesta)

- Direktiva Seveso II s amandmanima

- Direktiva o odgovornosti za okoliš (2004/35/EC)

- Dokument koji se bavi najboljim mogućim tehnologijama (BAT) vezanim za rudarski otpad u okviru IPPC Direktive (BREF)

- EU Direktiva o registru zagađenja i rudarskom otpadu

\subsubsection{Predviđanje buduće potražnje za kamenim agregatima}

Kad je u pitanju buduća potražnja za agregatima u određenom području, važno je uspostaviti kratkoročne, srednjoročne i dugoročne scenarije opskrbe i potražnje (tj. predviđanja) za agregatima, pritom uzimajući u obzir buduće potencijale za opskrbu, 
uključujući primarne i sekundarne agregate. Na temelju takvih scenarija opskrbe i potražnje mogu se razviti koncepti namjene zemljišta u svrhu opskrbe agregatima (uključujući i analize toka materijala kod različitih neophodnih primjena).

Predviđanje potražnje može se temeljiti na stručnoj procjeni, ili na nekoj vrsti kvantitativnog modela. Svaki model će posjedovati sebi svojstvenu razinu složenosti i detaljnosti, teorijsku osnovu i metodu primjene. Oni koji se temelje na sektorskim karakteristikama nazivaju se modelima odozdo prema gore; oni koji se zasnivaju na intenzitetu upotrebe su modeli odozgo prema dolje. Sektorski modeli obično predstavljaju ili hipotetički uzročno-posljedični odnos, ili ekstrapolaciju trenda niza opažanja prikupljenih tijekom vremena, odnosno podataka vremenskih serija. Prvi su modelirani uz pomoć jedne ili više ekonometrijskih regresivnih jednadžbi koje podrazumijevaju da potražnja ovisi o jednoj ili više nezavisnih eksplanatornih varijabli, recimo ekonomskoj aktivnosti ili stanovništvu. Druga vrsta modela podrazumijeva da će se obrazac potražnje kakav je bio u prošlosti nastaviti i u budućnosti (Agioutantis i dr., 2014).

\section{Primjer teksta}

Plan daje procjenu mogućih potreba za sirovinama i, nakon što je istražio različite opcije koje su na raspolaganju, utvrđuje najbolja područja za eksploataciju koja će zadovoljiti te potrebe. Predviđanje moguće buduće potražnje za mineralnim sirovinama trebalo bi biti osnova za procjenu mogućih potreba.

\subsubsection{Identifikacija zona prioriteta i zona zaštite}

Područja s mineralnim sirovinama koje treba zaštititi su ona kod kojih ne postoji konflikt s drugim planovima za upotrebu prostora, ili je taj konflikt minimalan. Na njih se primjenjuje proces planiranja mineralnih sirovina koji se može pratiti, a koji je osmišljen tako da se izbjegnu konflikti pri eksploataciji sirovina.

Faza regionalnog planiranja je naročito značajna za reguliranje pitanja u vezi sa sirovinama. Uz pomoć preciznih iskaza, regionalni planovi (temeljeni na razvojnim planovima višeg nivoa, kao što su oni nacionalni i međuregionalni) određuju regionalne ciljeve prostornog planiranja. $U$ okviru plana mora se definirati izraz „prioritetne zone za sirovine" tako da iste budu osigurane, uzimajući u obzir srednjoročnu i dugoročnu potražnju za mineralnim sirovinama, kao i ograničenu dostupnost ležišta mineralnih resursa.

$\mathrm{Na}$ početku je potrebno razviti sistematsku identifikaciju i evaluaciju ležišta mineralnih sirovina u odnosu na potrebu njihove zaštite. Zatim slijedi druga faza „eliminiranja konflikata“ kojom se eliminiraju svi konflikti u vezi sa zaštitom područja s mineralnim sirovinama. Zadatak druge faze je odrediti „zone za mineralne sirovine 
kod kojih nema konflikata“, uzimajući u obzir i druga područja zaštićena zakonom kao što su: područja za stanovanje, nacionalni parkovi, prioritetne zone vodoopskrbe, područja zaštićenog krajolika, šume, područja zaštićena programom Natura 2000, itd.

Prilikom definiranja zona zaštićenih mineralnih sirovina, posebna pažnja će biti posvećena osiguravanju dostatne regionalne opskrbe građevinskim sirovinama koje se nalaze blizu pri površini i pokrivaju potrebe više generacija. $U$ odnosu na posebne grupe sirovina (npr., pijesak, šljunak, različite čvrste stijene, visokokvalitetni karbonati, gline, industrijski minerali, rude i energenti) treba razviti i posebne metode za evaluaciju.

Prilikom upotrebe metode pozitivnog planiranja, područja koja imaju druge prioritetne upotrebe izuzimaju se iz prostora kod kojih postoje ležišta koja vrijedi eksploatirati pa tako preostala područja postaju prioritetna nalazišta sirovina. Prednost ove metode je $u$ tome što nadležna tijela mogu primijeniti konkretnu politiku za sirovine. Problem koji se javlja kod pozitivnog planiranja su potencijalne špekulacije sa zemljištem.

Osim toga, a na osnovi austrijskog iskustva, treba spomenuti da eksploatacija agregata može biti dozvoljena i izvan prioritetnih zona za sirovine, npr., u poljoprivrednoj zoni - ako se općina s tim složi. To svakako ovisi o kvaliteti rješavanja konflikata između operatera i općine (i zainteresiranih građana).

\section{Primjer teksta:}

Odabir lokacija mora uzeti u obzir nacionalne politike očuvanja krajolika, povijesnih spomenika ili prirode, kao i poljoprivrednih zemljišta. Planovi trebaju i zaštititi mineralne sirovine za buduću eksploataciju te razviti kriterije za kontrolu razvoja, a koje novi zahtjevi za planiranje eksploatacije mineralnih sirovina moraju ispuniti.

Za potrebe Plana mineralnih sirovina, područja za sirovine definirana su kao sva područja koje su identificirana uz pomoć objektivnih i sistematičnih analitičkih metoda, a sadrže mineralne sirovine. U kontekstu očekivanog tehnološkog razvoja, a imajući u vidu ekološke i društvene aspekte, smatra se da će se takvi materijali moći komercijalno koristiti srednjoročno i dugoročno. Prema definiciji u Planu mineralnih sirovina, područja mineralnih sirovina koja treba zaštititi su ona kod kojih je konflikt s drugim upotrebama zemljišta minimalan ili ne postoji. Na njih se primjenjuje proces planiranja mineralnih sirovina koji se može pratiti, a osmišljen je tako da se izbjegnu konflikti kod eksploatacije sirovina. Njih treba očuvati za eksploataciju sirovina, ali ne treba postojati obveza za eksploatacijom mineralnih sirovina u ovako definiranim područjima. 


\subsubsection{Identifikacija alternativnih izvora}

Osiguravanje održive mješovite opskrbe agregatima podrazumijeva utvrđivanje odgovarajućih sekundarnih izvora agregata. Ovaj aspekt je strogo povezan sa strukturom plana gospodarenja otpadom (ukoliko takav plan postoji u zemlji).

U pogledu održivosti, politiku i zakonodavstvo treba primijeniti na način da se sekundarne sirovine koriste koliko god je to moguće. No, to ovisi i o strukturi tržišta recikliranja i cijenama. To ne samo da umanjuje potrebu za primarnim resursima, $i$ produžava dostupnost prirodnih resursa budućim generacijama, već i smanjuje količine industrijskog otpada koje se odlažu na deponije. Stoga svaki koncept opskrbe agregatima treba podrazumijevati odgovarajuće alate $i$ instrumente kojima se povećava upotreba sekundarnih resursa.

\section{Primjer teksta:}

Tijela nadležna za planiranje mineralnih sirovina trebaju surađivati s drugim relevantnim institucijama $i$ uz pomoć najboljih dostupnih informacija napraviti projekciju potražnje za agregatima, vodeći računa o mogućnostima korištenja sirovina iz sekundarnih i drugih izvora koji mogu biti odgovarajuća alternativa primarnim sirovinama.

\subsubsection{Definiranje kriterija i smjernica za lokalna područja eksploatacije}

Plan bi trebao definirati kriterije i smjernice za lokacije rudarskih područja od općinskog značaja, temeljene na korištenim resursima, predviđenoj potražnji, fizičkim faktorima i zaštiti okoline, potrebama da se prostor sačuva za druge namjene, kao i zaštiti prirodnih resursa (npr., podzemnih voda).

\section{Primjer teksta:}

Općinski rudarski planovi pripremljeni su na temelju odredbi sadržanih u nacionalnom/regionalnom planu, a posebno onih koje se odnose na određivanje zona prioriteta.

Općinski rudarski plan popraćen je izvješćem s objašnjenjima, adekvatnim kartografskim zapisima i primijenjenim tehničkim standardima, i utvrđuje:

a) zone s ograničenjima definiranih zakonom, relativne količine koje se mogu eksploatirati, kao i lokacije povezanih sustava;

b) konačno korištenje područja zahvaćenih rudarskim aktivnostima;

v) dogovori za eksploataciju i konačno rješenje za kamenolome, uključujući i one napuštene;

e) metode upravljanja;

f) mjere kojima se predviđeni negativni utjecaji svode na najmanju moguću mjeru. 


\subsubsection{Osiguravanje konkurentnosti u industriji agregata}

Europsko udruženje proizvođača agregata (UEPG - European Aggregates Producers Association) navodi: „Nema građevinarstva bez agregata“. Danas je industrija agregata najvažniji izvor sirovina (Bressi i dr. 2011), a regulacija (ili de-regulacija) tržišta ključna je za osiguravanje konkurentnosti i promicanje održivih pristupa.

Sigurnost investicije od ključne je važnosti za operatera. Prilikom izdavanja dozvola za eksploataciju kamenoloma čvrstih stijena treba razmotriti izdavanje dozvole na 50 godina (potvrđene rezerve agregata). Nijedna dozvola ne bi trebala biti na rok manji od 15 godina, jer se u suprotnom niti jedna kapitalna investicija ne može isplatiti. $U$ svakom slučaju, treba procijeniti trajanje svake dozvole uzimajući u obzir dostupnu količinu agregata, očekivanu potražnju i najbolje dostupne tehnike eksploatacije. Kod eksploatacije pijeska ili šljunka, dozvole bi trebale vrijediti 15-50 godina, ovisno o veličini ležišta, s očekivanim obnavljanjem dozvole također proporcionalnim $s$ veličinom ležišta. Prilikom izdavanja dozvola, njihovo trajanje treba uvijek biti u skladu sa životnim vijekom ležišta: održivost zahtijeva eksploataciju čitavog ležišta (Cibin i dr., 2011).

U tom pogledu mogu se javiti određeni problemi, naročito kada su u pitanju nelitificirane naslage poput ležišta pijeska i šljunka, i potencijalni sukob $s$ vodoopskrbom, praksama za očuvanje okoline, ili onima za smanjenje negativnih utjecaja na okoliš te praksama obnove. Takvi problemi mogu rezultirati time da se eksploatira samo dio ležišta.

Mora se primijetiti da integrirana upotreba prirodnih i recikliranih agregata, osim što osjetno štedi prirodne resurse, može omogućiti bolje iskorištavanje raspoloživih resursa prema različitim namjenama.

$\mathrm{Na}$ slobodnom tržištu javlja se niz faktora koji bi trebali/mogli dati prednost korištenju recikliranih agregata u odnosu na prirodne. To su:

- Niža cijena nego kod prirodnih sirovina;

- Visoka potražnja za materijalima niskih performansi (za posipanje putova, zatrpavanje, nasipe, itd.);

- Smanjenje troškova transporta (koji mogu biti niži zato što je postrojenje za reciklažu obično bliže nego kamenolom, a mogu se anulirati u slučaju proizvodnje na licu mjesta).

Niska cijena je bez sumnje najvažniji poticaj pri odabiru recikliranih proizvoda, jer je to jedan od odlučujućih faktora na javnim natječajima. Nadalje, vlade također mogu razviti politike GPP (Green Public Procurement) - „zelenih“ javnih nabava sa širokim rasponom ciljeva, uključujući i povećanje udjela potrošnje recikliranih materijala u 
građevinskim aktivnostima i povećanje učinkovitosti resursa. Kada govorimo o GPP, pretjerano inzistiranje na smanjenju inicijalnih troškova može dovesti do toga da se nadležni odluče za energetski manje učinkovito rješenje, čak $\mathrm{i}$ onda kada bi učinkovitije rješenje dovelo do dugoročnih ušteda državnih sredstava. Kao što je ranije spomenuto, to nije slučaj s recikliranim agregatima, tako da su u tom slučaju svi na dobitku.

$\mathrm{Na}$ kraju, što se tiče djelomične naknade troškova proizvodnje vezanih uz rad koji je neophodan da bi se garantirala stalnost karakteristika recikliranih agregata (kontrola proizvodnje u tvornici), proizvođači mogu računati na naknade koje se plaćaju za odlaganje otpada u tvornici. lako su u pitanju ograničena sredstva, ona omogućuju da se proces reciklaže nastavi na gotovo svakom mjestu.

\section{Primjer teksta:}

Trajanje dozvole ne bi trebalo biti duže od pedeset godina, ali po pravilu ni manje od deset. Mi prepoznajemo da treba djelovati u skladu s principom održivog razvoja te štititi i očuvati okoliš: plan će se baviti načinima kako poboljšati ekološke performanse proizvoda tijekom čitavog njihovog životnog ciklusa; to će podrazumijevati rad na ekonomskim poticajima za proizvode koji su ekološki, povećavanje potražnje za „zelenim" proizvodima kroz bolje informiranje kupaca, razvoj objektivnog temelja za zelene javne nabave, kao i rad na stimuliranju proizvodnih postupaka koji su u većoj mjeri ekološki.

\subsubsection{Usvajanje najboljih dostupnih tehnologija tijekom cjelokupnog procesa}

Postoje mnoge tehnologije čiji je cilj smanjenje indirektnih utjecaja (vezanih za eksploataciju i transport agregata) na atmosferu, površinske vode i biosferu.

Tvrtke obično investiraju u najbolje dostupne tehnologije onda kada je neophodno zadovoljiti neke zakonski uvjete i izbjeći plaćanje kazne. Uz odgovarajuću edukaciju, operateri mogu postati aktivni sudionici u procesu održivije proizvodnje agregata. Štoviše, mnoge tvrtke će dati veći doprinos lokalnoj zajednici od onoga na koji ih obavezuje zakon, poput sufinanciranja sportskih i kulturnih aktivnosti i sličnih događaja, kako bi održavale dobre odnose s lokalnom zajednicom.

Operateri koji eksploataciju u kamenolomima trebaju biti svjesni da je eksploatacija mineralnih sirovina koja je odgovorna prema okolišu i javnosti od ključnog značaja za budućnost tvrtke. Današnje kompanije se općenito trude održati „korporativnu društvenu odgovornost" na visokom nivou. Stoga, poslovni subjekti prihvaćaju odgovornost za utjecaj svojih aktivnosti na okoliš, potrošače, zaposlenike, zajednice i dionike. 
Kada je u pitanju proizvodnja primarnih agregata, tvrtke koje se bave ovom djelatnošću mogu dobiti ekološke certifikate (ISO 9000/ISO 14000) na osnovi zadovoljavanja određenih tehničkih i ekoloških zahtjeva. Eksploatacija se može obavljati na način kojim nastaju minimalne količine otpada.

Također, u području proizvodnje sekundarnih agregata postoje mnoge suvremene tehnologije koje se koriste za obradu građevinskog otpada i proizvodnju kvalitetnih recikliranih agregata koji se svojim tehničkim karakteristikama mogu usporediti s primarnim agregatima. Ove tehnologije su dostupne bilo kao mobilna postrojenja za preradu koja se montiraju na gradilištu ili kao posebni stacionarni pogoni za reciklažu.

Evaluacija performansi postrojenja za preradu može se obaviti uz pomoć alata za planiranje $\mathrm{i}$ to praćenjem skupa indikatora čiju evaluaciju treba obaviti tijekom postupka izdavanja dozvole za rad.

lako to ne spada strogo u domenu plana mineralnih sirovina, treba primijetiti da metode koje se koriste prilikom rušenja značajno utiču na proces recikliranja koji nakon toga slijedi, kao i na tehničke karakteristike recikliranih proizvoda. Sortiranje otpada od gradnje i rušenja u homogene segmente na samom izvoru smanjuje troškove recikliranja i odlaganja (tamo gdje je primjenljivo) i osigurava bolju kvalitetu recikliranih proizvoda. Ovo treba uključiti u plan gospodarenja otpadom kako bi se povećala ukupna učinkovitost.

\section{Primjer teksta:}

Nacionalni plan definira potrebu za razradom općinskih planova putem izvješća s objašnjenjima, adekvatnim kartografskim podacima i primijenjenim tehničkim standardima koji se tiču metode eksploatacije i konačne organizacije kamenoloma, uključujući i one napuštene.

\subsubsection{Definiranje kriterija konačne iskoristivosti nakon zatvaranja}

Rudarske aktivnosti nužno su povezane s utjecajem na reljef. To se naročito odnosi na privremeno korištenje površina kod površinskih kopova, ali također i na dugoročno ili trajno korištenje, kao u slučaju odlagališta.

Definiranjem plana za obnovu još prilikom planiranja budućeg kamenoloma izbjegava se da stari/napušteni kamenolomi postanu prostori za nekontrolirano odlaganje različitih vrsta otpada. Da bi se osigurala provedba plana obnove, neophodno je osigurati ekonomske resurse, npr., putem garancija.

Za postizanje boljih rezultata sanacije i obnove napuštenih eksploatacijskih polja, planiranje obnove treba uklopiti u specifične okolišne uvjete svakog pojedinog polja. 
Ukoliko potpuna oporaba nije moguća, treba razmisliti o instalaciji postrojenja za reciklažu u blizini kamenoloma na kojima je završena eksploatacija, onda kada se razmatra njihova namjena nakon zatvaranja.

\section{Primjer teksta:}

Prema Zakonu o rudarstvu, rudarska aktivnost ne prestaje završetkom eksploatacije mineralnih sirovina $i$ odlaganjem jalovine. Sanacija predstavlja integralan dio rudarske aktivnosti. Rudarski subjekti koji obavljaju eksploataciju obvezani su zakonom da saniraju eksploatirane lokalitete. Interesi pogođenih zajednica $i$ ekosustava uzimaju se u obzir u najranijoj fazi procesa planiranja, prije početka same eksploatacije.

\subsubsection{Uspostavljanje koordinacije između tijela nadležnih za izdavanje dozvola}

Poboljšanje koordinacije između postupaka/tijela za izdavanje dozvola i tijela vlasti za prostorno planiranje. Koherentna politika planiranja agregata mora se temeljiti na relevantnim podacima i informacijama (geologija, lokacija, kvantiteta i kvaliteta ležišta mineralnih sirovina najčešće su dobro poznati). Da bi se definirao potencijal jednog područja kada su u pitanju resursi agregata, moraju se uzeti u obzir i ograničenja koja potječu od specifične namjene prostora i prisutnosti zaštićenih područja. Nakon što se procijeni potencijal, za finaliziranje plana je potrebno precizno poznavanje potražnje za agregatima, informacija o količinama eksploatiranih agregata te informacija o stopi recikliranja na razini regije; međutim, ovi podaci zahtijevaju dobru koordinaciju među različitim tijelima vlasti.

Nadalje, zakonodavstvo ne bi trebalo generirati preklapanja upravnih nadležnosti između različitih tijela koja se bave planiranjem. S hijerarhijske točke gledišta, lokalni plan bi se trebao jasno uklapati u okvir nacionalnog plana.

Glavni plan bi se obično trebao baviti predviđanjima potražnje/opskrbe, pitanjima uvoza/izvoza i prekogranične suradnje, ekonomskom, socijalnom i ekološkom ravnotežom, kao i strogim vezama s planiranim korištenjem prostora, npr., pri definiranju «prioritetnih područja za agregate».

Određeni aspekti koji su u vezi sa SARM-om i SSM-om trebali bi biti dio nacionalne/regionalne regulative vezane za rudarstvo, a to su:

- Efikasnost resursa, odnosno izbjegavanje stvaranja otpada;

- Upotreba najviših tehničkih standarda vezanih za zaštitu okoliša;

- Koncepcija transporta u skladu s prometnim principima koji su na snazi u općinama; 
- Osiguranje sredstava za obnovu;

- Naročito razmatranje planiranja korištenja prostora prilikom izdavanja dozvola;

- Javni interes - mora se osigurati opskrba agregatima na širem planu.

Općinski planovi eksploatacije detaljnije opisuju okvir koji je definiran glavnim planom, a kod decentraliziranog pristupa ovi planovi napokon određuju područja koja su potencijalno pogodna za eksploataciju od strane privatnih osoba. Plan obnove obično uključuje procjenu utjecaja na okoliš i neke mjere za smanjenje ovih utjecaja.

\section{Primjer teksta:}

Općinski plan [za agregate] priprema se na osnovu odredbi sadržanih u Nacionalnom planu, a naročito onih koje se odnose na eksploataciju u prioritetnim zonama za agregate. Općinski plan se usvaja i prihvaća s postupcima predviđenim za opće sheme planiranja; savjetodavno tijelo je u ovom slučaju [nacionalna] tehnička Komisija za rudarstvo.

Tehnička Komisija (na nacionalnom nivou) se bavi rudarskim aktivnostima i ima savjetodavnu ulogu u slučajevima koji su propisani zakonom.

Komisija se bira na pet godina i ima sljedeći sastav:

a) Regionalni savjetnik koji ima nadležnost u ovim pitanjima, s ulogom Predsjedavajućeg; njega u odsustvu može zamijeniti zamjenik koji se bira među članovima Komisije;

b) Pet stručnjaka u disciplinama geologije, rudarstva, poljoprivrede $i$ šumarstva, gospodarstva, prava, ekološkog planiranja i urbanističko-teritorijalnog planiranja, a koje bira Regionalni savjet iz redova znanstvenika i tehničara dokazane znanstvene stručnosti i profesionalnog iskustva;

c) Tri stručnjaka iz istih disciplina koje bira Regionalni savjet iz redova zaposlenih $u$ regionalnim tijelima koja se bave ovim mineralnim sirovinama.

\subsubsection{Postupci za izdavanje dozvola trebaju biti djelotvorni i učinkoviti}

Preporučuje se pristup sve na jednom mjestu, u kojem svi uključeni odjeli koordiniraju učinkovito jedni s drugima. Također se podrazumijeva da će se postupak izdavanja dozvola temeljiti na planiranju korištenja prostora i upravljanja prostorom, barem u pogledu odabira prioritetnih zona za sirovine.

U kontekstu planiranja, pravni izuzeci ne olakšavaju identifikaciju područja pogodnih za eksploataciju i treba ih izbjegavati ako je to moguće. 
Provođenje rudarske aktivnosti odobrava načelnik općine (ili drugo ovlašteno tijelo), isključivo u područjima koje su specificirana u Planu rudarskih aktivnosti, prema savjetu Tehničke komisije za rudarske aktivnosti i nakon definiranja odnosa između koncesionara i države.

\section{Primjer izuzetka:}

Postoji izuzetak, kada se resursi agregata nalaze u području koje je prema zakonu klasificirano kao državna imovina (državna imovina je pokretna ili nepokretna imovina koja pripada lokalnim vlastima, odnosno državi, regiji, pokrajini ili općini). Ovakvi agregati su stoga vlasništvo javnog tijela koji je nosilac vlasništva nad zemljištem koje se obično sastoji od jezera, riječnog toka ili obale. U ovakvim slučajevima, lokalne vlasti mogu izdati dozvolu za eksploataciju u određenim okolnostima i u određenim slučajevima (npr. kada je u pitanju nusproizvod zaštitne ili hidrauličke intervencije, s ciljem da se osigura funkcionalan vodni sustav ili sanacija vodenog toka).

\subsubsection{Provođenje potrebe za ravnotežom u okolišu}

Plan bi trebao uključiti procjenu utjecaja na okoliš (EIA - environmental impact assessment) u postupak osnovnog plana poslovanja s posebnim propisima koji će uzeti u obzir dinamičan karakter rudarskih aktivnosti. Plan bi trebao sadržavati popis mogućih rudarskih projekata koji će podlijegati ElA-u (u skladu sa površinom polja ili količinama koje će se eksploatirati). Da bi se garantiralo sudjelovanje javnosti i svih dionika, odobravanje osnovnog plana poslovanja koji uključuje EIA od strane tijela nadležnih za rudarstvo odvija se prema formalnoj proceduri za odobravanje planova, uz sažimanje postupaka za dobivanje svih potrebnih paralelnih dozvola (sve na jednom mjestu). Ovakav postupak omogućava da se svi problemi koji se javljaju ispitaju od strane svih administrativnih tijela i dionika te daje investitorima potrebnu pravnu sigurnost.

\section{Primjer teksta:}

Svi projekti eksploatacije koji podrazumijevaju više od $500.000 \mathrm{~m}^{3} / \mathrm{g}$ eksploatiranog materijala, ili površinu veću od 20 ha, moraju proći kroz postupak procjene utjecaja na okoliš. 


\section{Literatura}

- Agioutantis, Z. i dr. (2014), Handbook on Data and Analysis Methodologies for Aggregates Planning: A joint manual for planning authorities in SEE region, SNAP-SEE, 2014

- $\quad$ Cibin, U., Cera, M.C., Spotorno, C., Furin, S., Pelosio, A. , Romagnoli, M., Rizzati, A.R., Marasmi, C. (2011), SARMa Activity 4.2 (SSM) Synthesis Report. http://www.sarmaproject.eu/uploads/media/SARMa_Report_Sustainable_S upply_Mix_01.pdf

- Council Directive 89/106/EEC of 21 December 1988 on the approximation of laws, regulations and administrative provisions of the Member States relating to construction products. Official Journal L 40, 11.02.1989, p. 12-26 http://eur-lex.europa.eu/legal-content/en/ALL/?uri=CELEX:31989L0106

- CSES (Centre for Strategy and Evaluation Services) 2014. Final Report on "Evaluation and Exchange of Good Practices for the Sustainable Supply of Raw Materials within the EU" - ANNEX A - GOOD PRACTICE CASES. http://ec.europa.eu/DocsRoom/documents/4878/attachments/1/translatio ns/en/renditions/pdf

- Dolinar U., Softic M. i Kozinc Z. (2014), Handbook on Consulting Stakeholders when Applying Best Practices in Sustainable Aggregates Planning, SNAPSEE, 2014

- European Commission (2011). Resource-efficient Europe MEMO/11/43 26/01/2011 http://europa.eu/rapid/press-release_MEMO11-43_en.htm?locale=en

- Hámor, T., Tiess, G., Kager, J., Heimburg, J. (2011). European Community Law relevant to aggregates: SARMa - Review of EU Community Legislation A framework recommendation http://www.sarmaproject.eu/uploads/media/SARMa_Report_EU_Law.pdf

- Hámor, T. (2012). Recommendations for effective aggregate policy and management, covering the legal and regulatory solutions with regard to sustainable aggregate resources management http://www.sarmaproject.eu/uploads/media/SARMa_Recom_Aggreg_Policy _01.pdf

- Horváth, Z., Miko, S., Sári, K. i Dedić, Ž. (2014) A Vision of Best Practices for Aggregates Planning in South East Europe, SNAP-SEE, Ljubljana, 56 p. 
- IISD (International Institute for Sustainable Development). 2004. National Strategies for Sustainable Development: Challenges, Approaches and Innovations in Strategic and Co-ordinated Action. IISD, Winnipeg, CA.

- Tiess, G., 2010. Minerals Policy in Europe: Some Recent Developments. Resour. Policy 35, 190-198.

- UEPG, 2010. Planning Policies and Permitting Procedures to Ensure the Sustainable Supply of Aggregates in Europe.

http://www.minpol.com/LeobenReview_final-final_060610.pdf

- Weber, L., 2012 (Der Osterreichische Rohstoffplan Archive fur Lagerstattenforschung 26, 264 S. Geol B-A, Wien) The Austrian Mineral Resources Plan. Arch. f. Lagerst.forsch Geol. B.-A. Band 26, pp. 1-264. Wien, June 2012. http://opac.geologie.ac.at/wwwopacx/wwwopac.ashx?command=getconte nt\&server=images\&value=AL0026_001_A.pdf 


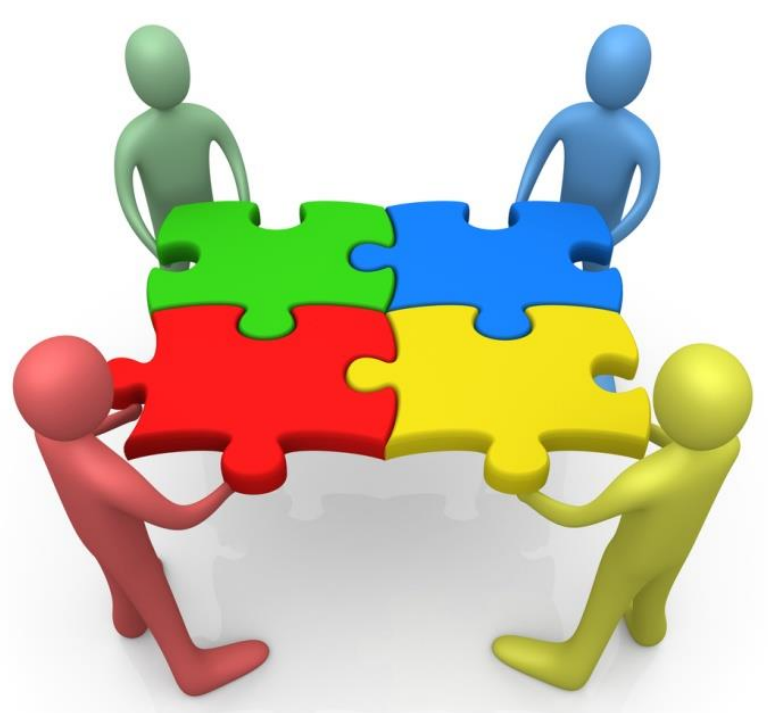

Održivo planiranje kamenih agregata u jugoistočnoj Europi

Sustainable Aggregates Planning in South East Europe (SNAP-SEE) 